\title{
Het belang van een dynamische weergave van acties voor personen met afasie
}

\author{
Lindy Geerink ${ }^{1,2}$, Anne Pross ${ }^{1}$, Janneke Brouwer de Koning ${ }^{1}$, \\ Joyce Blankestijn-Wilmsen², Ilona Damen², Vicky Voorbraak-Timmerman², \\ Joost Hurkmans $^{3}$, Roel Jonkers ${ }^{1}$ \\ ${ }^{1}$ Afdeling Taalwetenschap, Rijksuniversiteit Groningen \\ ${ }^{2}$ Roessingh, Centrum voor Revalidatie, Enschede \\ ${ }^{3}$ Revalidatie Friesland, Beetsterzwaag
}

\begin{abstract}
Samenvatting
Binnen wetenschappelijk onderzoek en logopedische diagnostiek en therapie met betrekking tot het begrijpen en oproepen van werkwoorden wordt er voornamelijk gebruik gemaakt van statisch weergegeven acties. Uit diverse studies blijkt echter dat bij personen met afasie het begrip en de productie van acties significant beter is indien de acties dynamisch weergegeven worden in de vorm van video's in plaats van statisch in de vorm van foto's. Er zijn echter ook studies die dit tegenspreken. In de huidige studie werden drie experimenten uitgevoerd waarin onderzocht werd wat de invloed is van een statische en dynamische weergave van acties op het begrijpen en benoemen van acties. Daarnaast werd er onderscheid gemaakt in drie semantische categorieën, namelijk ARM-gerelateerde, BEEN-gerelateerde en GEZICHT-gerelateerde acties. Ook werd onderzocht in hoeverre het onderliggende afasietype van invloed is op het begrijpen van acties op basis van de tweedeling tussen een vloeiend afasietype en een niet-vloeiend afasietype. Uit de resultaten blijkt dat personen met afasie significant beter presteren op zowel het benoemen als begrijpen van acties op woord- en zinsniveau wanneer deze acties dynamisch worden weergegeven. Op taalbegripsniveau is het onderliggende afasietype hierop niet van invloed. Daarnaast werd aangetoond dat een dynamische weergave van ARM- en BEEN-gerelateerde acties het begrip van deze acties verbetert vergeleken met een statische weergave. Voor de productie van acties geldt dit alleen voor ARMgerelateerde acties. De gevonden resultaten sluiten gedeeltelijk aan bij recente theorieën op het gebied van de mentale opslag van werkwoorden. Gezien het voordeel van een dynamische weergave van acties voor het benoemen en begrijpen van acties voor personen met afasie verdient het aanbeveling om hier rekening mee te houden binnen de logopedische diagnostiek en therapie.
\end{abstract}

Lindy Geerink, MA. Roessingh, Centrum voor Revalidatie, afdeling logopedie, Roessinghsbleekweg 33, $7522 \mathrm{AH}$, Enschede.

E-mail: 1.geerink@roessingh.nl 
GEERINK, PROSS, BROUWER DE KONING, BLANKESTIJN-WILMSEN, DAMEN, VOORBRAAK-TIMMERMAN, HURKMANS, JONKERS

\begin{abstract}
Summary
In naming and comprehension studies on verb processing mostly pictures or photographs depicting actions are used, although the meaning of verbs regularly involves movement. Several studies have shown that in verb comprehension and retrieval persons with aphasia (PWA) profit from a dynamic display of actions (video clips) in comparison to a static depiction (pictures). However, other studies provide contradictory outcomes. In the current study three experiments were conducted examining the influence of a static or dynamic display of actions in verb comprehension and action naming. In addition, a distinction was made in three semantic verb categories, namely arm-related, leg-related and face-related actions. Furthermore, the role of the underlying type of aphasia was considered for comprehension. The results show that people with aphasia perform significantly better on both naming and understanding actions in isolation and in sentences after a dynamic than after a static display. The underlying type of aphasia had no influence for the verb comprehension. In addition, it was found that a dynamic display of specifically arm- and leg-related actions improves the understanding of these actions compared to a static depiction. For the production of these actions this only holds for the arm-related actions. These results are partially in line with recent theories about the mental storage of verbs. Given the advantage of a dynamic display of actions for naming and understanding actions for PMA, it is recommended to take this into account in aphasia diagnosis and treatment.
\end{abstract}

\title{
Inleiding
}

Personen met afasie (PMA) ondervinden moeilijkheden met taal op zowel productie- als begripsniveau. De lokalisatie en de grootte van de laesie zijn bepalend voor de aard en de ernst van deze problemen. Bij de taalproductie ervaren PMA veelal woordvindingsproblemen. Vaak is het oproepen van werkwoorden gestoord. Problemen met het benoemen van acties lijken vaker voor te komen dan problemen met het benoemen van objecten (Mätzig, Druks, Masterson \& Vigliocco, 2009; Willams \& Canter, 1987). Zelfstandige naamwoorden zouden volgens Williams en Canter (1987) minder semantisch complex zijn dan werkwoorden, aangezien zelfstandige naamwoorden in de meeste gevallen verwijzen naar objecten, terwijl werkwoorden verwijzen naar acties, die vaak een handeling uitdrukken. De productie van werkwoorden zou moeilijker zijn voor personen met afasie doordat er meer informatie grammaticaal gecodeerd moet worden dan bij zelfstandige naamwoorden. Daarbij spelen zowel grammaticale factoren, bijvoorbeeld argumentstructuur, als lexicale factoren zoals woordfrequentie een rol (Bastiaanse \& Van Zonneveld, 2004). Uit diverse studies is gebleken dat de argumentstructuur in sterke mate bepalend is voor de oproepbaarheid van werkwoorden. Er werd aangetoond dat hoe meer argumenten een werkwoord heeft, hoe moeilijker het op te roepen is (Kim \& Thompson, 2000; Thompson, 2003; Kim \& Thompson, 2004). Ook kan voorstelbaarheid een rol spelen bij het oproepen en begrijpen van werkwoorden. Over het algemeen komt het vaker voor dat een stoornis in het semantische systeem leidt 


\section{HET BELANG VAN EEN DYNAMISCHE WEERGAVE VAN ACTIES VOOR PERSONEN MET AFASIE}

tot een beter begrip van hoogvoorstelbare werkwoorden, zoals 'lopen' dan van laagvoorstelbare werkwoorden zoals 'denken' (Bastiaanse, 2011). Men suggereert dat dit komt doordat concrete of hoogvoorstelbare werkwoorden meer perceptuele kenmerken hebben binnen de semantische representatie, hetgeen het begrijpen gemakkelijker maakt (Grossman et al., 2002). Actiewoorden hebben immers een rijke en uitgebreide set van geassocieerde perceptuele en motorische kenmerken (Grossman et al., 2002), in tegenstelling tot abstracte werkwoorden (Plaut \& Shallice, 1993; Schwanenflugel, 1991; Schwanenfluger \& Shoben, 1983). Overigens hebben Jonkers en Bastiaanse (2007) aangetoond dat werkwoorden, ook als deze gematcht zijn voor voorstelbaarheid met zelfstandige naamwoorden, moeilijker oproepbaar zijn.

Met betrekking tot het taalbegrip ervaren PMA vaak specifieke problemen met het begrijpen van werkwoorden. Diverse studies toonden aan dat zowel vloeiend als niet-vloeiend sprekende PMA werkwoorden slechter begrijpen dan zelfstandige naamwoorden (McCarthy \& Warrington, 1985; Miceli, Silveri, Nocenti \& Caramazza, 1988). De genoemde problemen kunnen zowel voorkomen op woord- als op zinsniveau en kunnen verschillen in ernst bij verschillende vormen van afasie (Grodzinsky, 1995; Jonkers, 1998).

\section{Statisch versus dynamisch}

Bij onderzoek naar werkwoorden wordt veel gebruik gemaakt van het benoemen van afbeeldingen. Tot op heden worden daar met name getekende afbeeldingen of foto's voor gebruikt. Vooral acties zijn moeilijk weer te geven met behulp van statisch materiaal, aangezien deze vaak een beweging impliceren. De hypothese is dat er met behulp van statisch materiaal maar een gedeeltelijke of incomplete representatie van de actie kan worden weergegeven, waardoor het begrijpen en het benoemen van de actie mogelijk moeilijker wordt voor PMA. Dynamisch materiaal, in de vorm van video's, kan de bewegingskenmerken van acties wel weergeven, waardoor de gehele uitvoering van de actie waargenomen kan worden. Dit zou kunnen leiden tot het beter benoemen van acties en een beter begrip van acties. Op basis van deze veronderstelling zijn er in het verleden diverse studies verricht naar de verschillen tussen het gebruik van statisch en dynamisch materiaal bij het begrijpen en benoemen van acties door personen met hersenletsel (Berndt, Mitchum, Heandiges \& Sandson, 1997; Tranel, Manzel, Asp \& Kemmerer, 2008; d'Honicthun \& Pillon, 2008; Druks \& Shallice, 2000; Fung et al., 2001). De uitkomsten van deze studies waren echter niet eenduidig.

Enkele studies vonden geen voordeel van een dynamische weergave ten opzichte van een statische weergave van acties bij de productie van deze acties door PMA (Berndt et al.,1997) en bij personen met een focale stabiele cerebrale laesie onder wie ook enkele PMA (Tranel et al., 2008). Tranel et al. toonden in hun studie aan dat er een hoge correlatie bestaat tussen het benoemen van acties in beide condities. De auteurs verklaren deze bevindingen op basis van de veronderstelling dat statisch weergegeven acties mentaal gesimuleerd worden in de hersenen (Tranel et al., 2008; Shiffrar \& Freyd, 1990; Verfaille \& Daems, 2002) en dat ze op dezelfde hersenstructuren een beroep doen als dynamisch weergegeven acties (Tra- 
GEERINK, PROSS, BROUWER DE KONING, BLANKESTIJN-WILMSEN, DAMEN, VOORBRAAK-TIMMERMAN, HURKMANS, JONKERS

nel et al., 2008). De gehanteerde methodologie in de betreffende studies zou echter ook van invloed kunnen zijn geweest op de gevonden resultaten. Zo konden de proefpersonen in de studie van Tranel et al. (2008) in de statische conditie meer tijd nemen om de afbeelding te bekijken dan tijdens de dynamische weergave van een actie, hetgeen volgens Tranel et al. waarschijnlijk tot betere prestaties op de statische conditie heeft geleid.

Daarentegen zijn er ook studies verricht die wel hebben aangetoond dat een dynamische weergave van acties leidt tot het beter benoemen van acties ten opzichte van een statische weergave bij PMA (Druks \& Shallice, 2000), bij personen met de ziekte van Alzheimer (Fung et al., 2001) en bij een persoon met fronto-temporale dementie (d'Honicthun \& Pillon, 2008). Druks en Shallice verklaren dit op basis van de veronderstelling dat een dynamische weergave van acties voor meer semantische informatie zorgt. Bij een dynamische weergave wordt het kenmerk 'beweging' weergegeven. Dit is een kenmerk dat van belang is bij acties. Door het zien van de beweging wordt bepaalde semantische informatie toegankelijk waardoor patiënten beter in staat zijn om de actie te benoemen dan wanneer ze het bewegingskenmerk niet zien, zoals bij een statische weergave. Volgens Fung et al. (2001) negeert het gebruik van statisch materiaal voor de weergave van acties de tijdsdimensie die essentieel is om concepten van acties volledig weer te geven. Zij vergeleken het gebruik van statisch materiaal voor de weergave van acties met het afbeelden van objecten waarvan men bepaalde delen van de objecten zou weglaten, bijvoorbeeld een stoel zonder stoelpoten. Hierdoor wordt de informatie uit de semantische context beperkt (Fung et al., 2001).

Net zoals geldt voor het benoemen van acties, zijn de resultaten met betrekking tot de invloed van de wijze van aanbieding op het begrip van acties op woordniveau ook niet consistent. Berndt et al. (1997) vonden binnen hun onderzoek bij 11 PMA geen significant verschil tussen het begrijpen van acties in de statische en dynamische conditie. Volgens Berndt et al. suggereert dit dat de selectieve werkwoordstoornissen niet te wijten zijn aan problemen om de acties binnen een statische weergave te identificeren. d'Honicthun en Pillon (2008) toonden aan dat een dynamische weergave van acties het begrip op woordniveau verbeterde bij de door hen onderzochte patiënt met fronto-temporale dementie. Dit toonden zij ook al aan voor de productie.

\section{De 'Embodied view of Cognition Theory', 'Disembodied View of Cognition Theory' en de neurale representatie van concepten}

\section{De 'Embodied Cognition Theory'}

Het idee dat dynamisch weergegeven acties het bewegende kenmerk van een actie beter kunnen weergeven dan statisch weergegeven acties sluit aan bij het onderzoek binnen de neurolinguïstiek dat zich bezighoudt met semantische aspecten van acties en objecten en de neurale representatie hiervan in de hersenen. De resultaten uit deze onderzoeken worden vaak in verband gebracht met de 'Embodied view of Cognition' theorie. 


\section{HET BELANG VAN EEN DYNAMISCHE WEERGAVE VAN ACTIES VOOR PERSONEN MET AFASIE}

De afgelopen 25 jaar zijn er talloze theorieën voorgesteld in het kader van de 'Embodied Cognition Theory' die de rol van perceptuele en motorische processen benadrukken voor hogere cognitieve vaardigheden zoals het begrijpen van acties. Hoewel er meerdere variaties zijn van deze theorieën, is de meerderheid van de onderzoekers het over ten minste twee conclusies eens (o.a. Barsalou, 2008; Gallese \& Lakoff, 2005). Ten eerste beweert men dat semantische kennis ligt opgeslagen in het sensomotorische systeem. Dit betekent dat de neurale systemen waarop de taal een beroep doet hetzelfde zijn als de hersensystemen die noodzakelijk zijn voor de waarneming en uitvoering van acties (Gallese \& Lakoff, 2005). Dit wil zeggen dat het begrijpen van een actie die uitgevoerd wordt door een andere persoon de bijdrage vereist van het eigen motorische systeem (Rizzolatti \& Sinigaglia, 2010). Ten tweede benadrukken de meeste 'Embodied Cognition Theories' het belang van simulatie tijdens de conceptuele verwerking van acties (Jeannerod, 2001; Zwaan \& Taylor, 2006). Dit houdt in dat dezelfde gebieden van de premotorische cortex betrokken zijn bij alle drie de condities: ten eerste het uitvoeren van acties, ten tweede het observeren van acties en ten derde het verwerken en begrijpen van woorden die verwijzen naar acties (Arévalo, Baldo \& Dronkers, 2012). Bijvoorbeeld, het ophalen van de semantische kennis van het actiewerkwoord 'lopen' zorgt voor activatie van het corticale gebied dat verantwoordelijk is voor de perceptie of de uitvoering van de motorische beweging 'lopen'. Het betreffende corticale gebied voert tijdens de conceptuele verwerking van het actiewerkwoord 'lopen' ook het proces uit dat normaal gesproken uitgevoerd zou worden tijdens de perceptie of het daadwerkelijk uitvoeren van de actie 'lopen'. Middels simulatie van de actie 'lopen' wordt de motorische kennis gebruikt om het actiewerkwoord 'lopen' te verwerken en te begrijpen.

\section{Semantische categorieën}

Verschillende studies naar de semantische aspecten van acties en de neurale representaties hiervan in de hersenen hebben bewijs geleverd voor de 'Embodied Cognition Theory'. Met betrekking tot deze semantische aspecten wordt er in de literatuur vaak onderscheid gemaakt tussen de semantische categorieën ARM, BEEN en GEZICHT. Dit wil zeggen dat de betreffende acties worden uitgevoerd met de arm/hand (bv. zwaaien), met het been/de voet (bv. lopen) of met het gezicht (bv. kussen). Uit een fMRI onderzoek van Hauk, Johnsrude en Pulvermüller (2004) bij 14 gezonde controleproefpersonen bleek dat deze semantische categorieën zorgen voor activatie in verschillende locaties in de hersenen tijdens een passieve leestaak. Zo leidde het lezen van woorden die ARM-acties uitdrukken tot activatie van de middelste frontale gyrus bilateraal in de premotorische cortex en de precentrale gyrus in de motorische cortex in de linker hemisfeer, terwijl BEEN-acties tot activatie in dorsale gebieden in de linker en middenlijn pre- en postcentrale gyri en in de premotorische cortex op de middenlijn dorsaal leidden. GEZICHT-acties leidden tot activatie van inferieure-frontale premotorische gebieden bilateraal.

Hauk et al. (2004) concludeerden dat het lezen van acties uit de categorieën ARM, BEEN en GEZICHT hersengebieden in de primaire motorische en premotorische gebieden acti- 
GEERINK, PROSS, BROUWER DE KONING, BLANKESTIJN-WILMSEN, DAMEN, VOORBRAAK-TIMMERMAN, HURKMANS, JONKERS

veert die ook actief zijn tijdens het daadwerkelijk bewegen van het been, de vingers of de tong. Deze resultaten wijzen op een somatotope weergave van de betekenis van actiewerkwoorden in de hersenen. Dat wil zeggen dat de betekenissen van actiewerkwoorden in de hersenen waarbij bepaalde lichaamsdelen zijn betrokken corresponderen met locaties op de primaire motorische schors en de premotorische cortex waar de handelingen van deze lichaamsdelen worden aangestuurd.

Bewijs dat pleit voor de 'Embodied Cognition Theory' werd ook al gevonden in eerder onderzoek naar de verwerking van ARM-gerelateerde, BEEN-gerelateerde en GEZICHT-gerelateerde acties (Pulvermüller, 2005; Pulvermüller, Härle \& Hummel, 2001; Pulvermüller, Hauk, Nikulin \& Ilmoniemi, 2005; Tettamanti et al. 2005). Terwijl de hierboven beschreven studies zich hebben gericht op woordniveau, hebben Tettamanti et al. (2005) vergelijkbare resultaten gevonden in hun fMRI-studie waarbij de proefpersonen alleen werden geacht naar zinnen te luisteren waarin acties voorkwamen die werden uitgevoerd met behulp van een arm (bv. 'Ik pak het mes'), een been (bv. 'Ik schop tegen de bal') of het gezicht (bv. 'Ik bijt in een appel').

De hierboven beschreven studies includeerden gezonde controlepersonen. Ook uit een onderzoek van Arévalo et al. (2012) bij personen met hersenletsel blijkt dat er een interactie bestaat tussen het motorische netwerk en het talige netwerk in de hersenen. Zij onderzochten met behulp van een semantische begripstaak de visuele en auditieve verwerking van acties gerelateerd aan bepaalde lichaamsdelen bij tien gezonde controlepersonen en 27 personen met een laesie in de linker hemisfeer ten gevolge van een Cerebro Vasculair Accident (CVA). In de studie werd onderscheid gemaakt tussen stimuli die geassocieerd worden met het gebruik van de mond, hand of voet en neutrale acties. Deze neutrale acties verwezen niet naar een lichaamsdeel. De patiëntengroep werd verdeeld in verschillende subgroepen gebaseerd op de aan- of afwezigheid van laesies in vier verschillende belangrijke sensomotorische gebieden. De resultaten toonden aan dat alle patiënten met een laesie in een van de gebieden minder accuraat presteerden op de VOET-gerelateerde items dan op de VOET-neutrale items. Dit betekent dat laesies in de primaire motorische en premotorische cortex, de somatosensorische cortex, de middelste temporale cortex en de inferieure frontale gyrus leiden tot problemen met het begrijpen van VOET-gerelateerde items. Voor de MOND- en HAND-gerelateerde stimuli werd geen significant verschil aangetoond, hoewel personen met een laesie in de somato-sensorische cortex ook slechter presteerden op de MOND-gerelateerde acties in tegenstelling tot de MOND-neutrale acties. Deze laesiedata suggereren dat er sprake is van een interactie tussen het motorische netwerk en het talige netwerk, maar dat deze associaties niet beperkt lijken te zijn tot een bepaald gebied in de premotorische/motorische cortex. In plaats daarvan lijken motorische-talige gebieden verspreid te zijn over verschillende corticale gebieden. Een stoornis in bepaalde gebieden van dit talige-motorische netwerk zal niet leiden tot een compleet onvermogen om de motorisch-geassocieerde concepten te verwerken, maar het kan resulteren in een toename van de problemen bij het activeren van de geassocieerde stimuli. Het was voor Arévalo et al. niet duidelijk waarom de VOET-gerelateerde acties een sterker effect lieten zien dan de 


\section{HET BELANG VAN EEN DYNAMISCHE WEERGAVE VAN ACTIES VOOR PERSONEN MET AFASIE}

andere condities. Volgens de auteurs zijn VOET-gerelateerde items minder opvallend dan items die verwijzen naar andere lichaamsdelen. Daarnaast gaven de auteurs aan dat VOETgerelateerde items misschien moeilijker zijn weer te geven in een tekening of foto. Het feit dat de MOND-gerelateerde items geen sterke effecten uitlokten kon verklaard worden doordat Arévalo et al. binnen deze items geen onderscheid hebben gemaakt tussen MONDgerelateerde items die gericht zijn op de communicatie en MOND-gerelateerde items die gericht zijn op het eten, zoals in andere studies wel is gedaan. Bij deze laatste MONDgerelateerde acties zou een dynamische weergave mogelijk tot betere resultaten leiden doordat deze acties sterkere motorische kenmerken hebben. Ook de resultaten van deze studie leveren gedeeltelijk bewijs voor de 'Embodied Cognition Theory'. Arévalo et al. suggereren echter dat motorische-talige gebieden verspreid zijn over verschillende corticale gebieden.

\section{De 'Disembodied View of Cognition Theory'}

De uitkomsten van de studie verricht door Arévalo et al. (2012) spreken de 'Embodied Cognition Theory' gedeeltelijk tegen aangezien de personen met een stoornis in de sensomotorische cortex nog wel in staat waren om werkwoorden te herkennen die gerelateerd waren aan mond-, hand-, of voet-gerelateerde acties. Daarom wordt in de huidige studie verondersteld dat de resultaten uit de bovenstaand beschreven onderzoeken niet alleen verklaard kunnen worden vanuit de 'Embodied Cognition Theory', maar ook vanuit de tegenhanger van deze theorie, de 'Disembodied View of Cognition Theory'. Volgens deze theorie worden concepten niet gevormd door informatie die is gerepresenteerd in het sensomotorische systeem, maar worden conceptuele representaties gezien als 'symbolisch' en 'abstract' en dus gescheiden van het sensomotorische systeem (Caramazza, Anzellotti, Strnad \& Lingnau, 2014; Chatterjee, 2010; Humphreys, Newling, Jennings \& Gennari, 2013; Mahon \& Caramazza, 2008). De resultaten van bovenstaande onderzoeken zouden op basis van de 'Disembodied View of Cognition Theory' verklaard kunnen worden vanuit de veronderstelling dat in een dynamische weergave het gehele proces van de actie weergegeven kan worden, terwijl een statische weergave maar een gedeeltelijke of incomplete representatie van de actie weergeeft aangezien maar één moment van het gehele proces van de actie weergegeven wordt (Fung et al., 2001). Deze incomplete weergave leidt tot meer problemen met de activatie van de abstracte en symbolische representatie van het concept, waardoor de informatie ook minder goed opgehaald kan worden uit de motorische systemen. Daarentegen geeft de dynamische conditie wel de motorische kenmerken van de actie weer waardoor het concept beter geactiveerd wordt waarna de informatie tevens beter opgehaald kan worden uit de motorische systemen, hetgeen leidt tot een beter begrip van de actie. Alle resultaten zoals hierboven beschreven zouden dus ook als zodanig kunnen worden gezien, aangezien in geen enkel onderzoek duidelijk is aangetoond dat de semantische informatie van acties ligt opgeslagen in het sensomotorische systeem in plaats van in 'abstracte' en 'symbolische' representaties. Ter ondersteuning van beide theorieën wordt er dus geen eenduidig resultaat gevonden dat pleit voor één van de theorieën. Een positief effect van dynamisch materiaal ten opzichte van statisch materiaal zou daarmee aan de hand van beide theorieën verklaard 
GEERINK, PROSS, BROUWER DE KONING, BLANKESTIJN-WILMSEN, DAMEN, VOORBRAAK-TIMMERMAN, HURKMANS, JONKERS

kunnen worden.

\section{Huidige studie}

Het gebrek aan consensus over de invloed van een dynamische en statische weergave van acties op het benoemen en begrijpen van actiewerkwoorden vormt de aanleiding tot de huidige studie. In de huidige studie zijn drie experimenten uitgevoerd. Deze hebben zich gericht op de prestaties van PMA op het benoemen en het begrijpen van statisch en dynamisch weergegeven acties. In experiment 1 werd onderzocht wat de invloed is van statisch versus dynamisch aangeboden acties op de productie van werkwoorden op woord- en zinsniveau. In eerdere studies werd voornamelijk onderzoek gedaan naar de productie van werkwoorden op woordniveau. In alledaagse taal komen werkwoorden echter voornamelijk voor in zinsverband. Er is daarom voor gekozen om in experiment 1 de productie van werkwoorden zowel op woord- als op zinsniveau te onderzoeken. Op basis van de literatuur die zich gericht heeft op de verschillen in prestaties tussen het benoemen van statisch weergegeven acties en het benoemen van dynamisch weergegeven acties wordt verwacht dat de PMA in het huidige onderzoek beter zullen presteren op de dynamisch weergegeven acties dan op de statisch weergegeven acties. In een dynamisch weergegeven actie kan volgens verschillende onderzoeken namelijk beter de belangrijkste informatie van een actie, de bewegende component, worden weergegeven. Dit in tegenstelling tot een statische weergave van een actie, waarbij deze bewegende component niet kan worden weergegeven (Druks \& Shallice, 2000; Fung et al., 2001; d'Honicthun \& Pillon, 2008).

In experiment 2 werd de invloed van statisch versus dynamisch aangeboden acties op de werkwoordproductie op woordniveau onderzocht, waarbij er onderscheid werd gemaakt in drie semantische categorieën, namelijkARM-gerelateerde, BEEN-gerelateerde en GEZICHTgerelateerde acties. Aangezien er nog maar weinig bekend is over de prestaties van patiënten met afasie op verschillende semantische categorieën wat betreft het oproepen van acties, zal de huidige studie zich hierop richten. Arévalo et al. (2012) wezen er in hun onderzoek op dat BEEN-gerelateerde acties moeilijker zijn uit te beelden en minder opvallend zijn dan ARM-gerelateerde en GEZICHT-gerelateerde acties. Verwacht wordt daarom dat de BEENgerelateerde acties in de statische conditie moeilijker te benoemen zullen zijn voor de patiënten met afasie dan de BEEN-gerelateerde acties in de dynamische conditie aangezien in de dynamische conditie de acties makkelijker uit te beelden zullen zijn en de bewegingscomponent van de actie kan worden weergegeven (Druks \& Shallice, 2000; Fung et al., 2001; d'Honicthun \& Pillon, 2008).

Overigens werd in de huidige studie gekozen voor GEZICHT-gerelateerde acties in plaats van MOND-gerelateerde acties zoals Arévalo et al. (2012) in hun onderzoek deden, omdat GEZICHT-gerelateerde acties een bredere categorie omvatten (bijv. 'knipogen', 'fronsen'). Ook werd er in het huidige onderzoek geen onderscheid gemaakt tussen GEZICHTgerelateerde items die gericht zijn op de communicatie en GEZICHT-gerelateerde items die gericht zijn op het eten, omdat er onvoldoende acties beschikbaar zijn om hiervoor te kun- 
HET BELANG VAN EEN DYNAMISCHE WEERGAVE VAN ACTIES

VOOR PERSONEN MET AFASIE

nen controleren.

Vervolgens werd in experiment 3 onderzocht wat de invloed is van statisch versus dynamisch aangeboden acties op het werkwoordbegrip op woord- en zinsniveau. Verwacht werd dat een dynamische weergave van acties een positievere invloed heeft op het begrijpen van werkwoorden op zowel woord- als zinsniveau dan een statische weergave van acties. De beweging wordt namelijk impliciet weergegeven in de statische conditie en volledig expliciet in de dynamische conditie. Dit kan betekenen dat een dynamisch aangeboden actie versterkte informatie geeft over de semantische context hetgeen het begrip verbetert.

Ook in experiment 3 werd er onderscheid gemaakt in de drie semantische categorieën ARM, BEEN en GEZICHT. Enkele onderzoekers hebben zich al gericht op de invloed van verschillende semantische categorieën op het begrip, maar hierbij werd voor zover bekend niet de vergelijking tussen een statische en dynamische weergave gemaakt. Gebaseerd op de resultaten van het onderzoek door Arévalo et al. (2012) wordt er voor het begrip, net zoals voor productie, verwacht dat de prestaties op BEEN-gerelateerde acties significant beter zijn in de dynamische conditie dan in de statische conditie, omdat BEEN-gerelateerde acties moeilijker weer te geven zijn op een foto en moeilijker uit te beelden zijn (Arévalo et al., 2012).

Bovendien werd in experiment 3 onderzocht of het onderliggende afasietype van invloed is op het verschil tussen de prestatie op de statische en dynamische conditie van de begripstaak. Dit werd gedaan op basis van de tweedeling tussen een vloeiend afasietype en een niet-vloeiend afasietype. Uit radiologisch onderzoek is namelijk gebleken dat het nietvloeiende afasietype bijna altijd veroorzaakt wordt door een anterieure laesie, waar het gebied van Broca zich bevindt, terwijl het vloeiende afasietype vrijwel steeds het gevolg blijkt te zijn van een posterieure laesie in de hersenen (Bastiaanse, 2011). In het kader van de somatotope weergave van de betekenis van actiewoorden in het brein wordt er verwacht dat het effect van de wijze van aanbieding verschillend is voor beide groepen. De lokalisatie van de stoornis verschilt namelijk tussen beide groepen en mogelijk bestaan er dus ook verschillen tussen de aan- of afwezigheid van een parese door de verstoring van het sensomotorische systeem, hetgeen mogelijk van invloed is op de prestaties op beide condities.

\section{EXPERIMENT 1: De invloed van statisch en dynamisch aange- boden acties op de productie van werkwoorden op woord- en zinsniveau}

\section{Proefpersonen}

Een groep van 18 PMA heeft deelgenomen aan experiment 1, waarvan dertien mannen en vijf vrouwen. De gemiddelde leeftijd was 55 jaar (range: 39-79 jaar). De afasie was het ge- 
GEERINK, PROSS, BROUWER DE KONING, BLANKESTIJN-WILMSEN, DAMEN, VOORBRAAK-TIMMERMAN, HURKMANS, JONKERS

Tabel 1: Overzicht van de individuele gegevens van de afasiegroep voor experiment 1

\begin{tabular}{|c|c|c|c|c|c|c|c|c|}
\hline $\mathbf{P P}$ & Geslach & t Leeftijd & Etiologie & TPO & $\begin{array}{l}\text { Score TT AAT } \\
\text { (fouten) }\end{array}$ & $\begin{array}{l}\text { Score AAT } \\
\text { benoemen }\end{array}$ & $\begin{array}{l}\text { Score spon- } \\
\text { tane taal IV }\end{array}$ & $\begin{array}{l}\text { Score spon- } \\
\text { tane taal VI }\end{array}$ \\
\hline $\mathrm{Al}$ & Vrouw & 39 & iCVA Links & 27 & 0 & 113 & 4 & 5 \\
\hline A2 & Man & 42 & IC hematoom & 31 & 44 & 33 & 3 & 2 \\
\hline A3 & Man & 63 & iCVA Links & 13 & 3 & 95 & 4 & 4 \\
\hline A4 & Man & 64 & iCVA Links & 17 & 11 & 98 & 4 & 4 \\
\hline A5 & Man & 43 & iCVA Links & 8 & 30 & 110 & 4 & 3 \\
\hline A6 & Man & 56 & iCVA Links & 37 & 6 & 126 & 5 & 4 \\
\hline A7 & Man & 50 & iCVA Links & 20 & 0 & 114 & 5 & 5 \\
\hline A8 & Man & 58 & iCVA Links & 8 & 4 & 104 & 4 & 4 \\
\hline A9 & Man & 79 & iCVA Links & 332 & 13 & 89 & 4 & 4 \\
\hline A10 & Vrouw & 46 & iCVA Links & 58 & 19 & 102 & 3 & 2 \\
\hline Al1 & Man & 65 & iCVA Links & 32 & 14 & 77 & 4 & 4 \\
\hline Al2 & Vrouw & 42 & HCVA Links & 10 & 14 & 99 & 4 & 3 \\
\hline A13 & Vrouw & 59 & iCVA Links & 132 & 33 & 84 & 3 & 2 \\
\hline Al4 & Man & 52 & iCVA Links & 36 & 8 & 110 & 4 & 4 \\
\hline A15 & Vrouw & 57 & iCVA Links & 152 & 31 & 57 & 4 & 4 \\
\hline A16 & Man & 52 & iCVA Links & 56 & 36 & 81 & 4 & 2 \\
\hline A17 & Man & 66 & iCVA Links & 8 & 21 & 103 & 5 & 5 \\
\hline A18 & Man & 65 & iCVA Links & 28 & 5 & 107 & 5 & 4 \\
\hline
\end{tabular}

volg van een ischemisch CVA in de linker hemisfeer, met uitzondering van proefpersoon A2 (intracerebraal hematoom) en proefpersoon A12 (hemorragisch CVA). De Time Post Onset (TPO) van de PMA was gemiddeld 14 maanden (range: 8-332 weken). Voor elke individuele patiënt zijn de scores van een aantal onderdelen van de Akense Afasie Test (AAT; Graetz, De Bleser \& Willmes, 1992) bepaald, waaronder de scores op de 'Token Test', de 'spontane taalproductie' op beoordelingsniveau 'syntactische structuur' en 'semantische structuur' en de scores van het onderdeel 'benoemen'. Personen met een woordvindingsstoornis en/of syntactische stoornis vastgesteld op basis van de AAT werden geïncludeerd in het onderzoek. De inclusiecriteria waren een score lager dan 5 in de categorie syntactische of semantische categorie op het onderdeel spontane taal en/of een score op het onderdeel benoemen kleiner of gelijk aan 107. De gegevens van de PMA worden weergegeven in tabel 1.

Daarnaast nam er een groep van 16 niet-taalgestoorde controleproefpersonen deel aan experiment 1 , bestaande uit zes mannen en tien vrouwen. Deze groep was gematcht met de groep PMA op basis van leeftijd. De gemiddelde leeftijd van de groep controleproefpersonen was 52 jaar (range: 31-67 jaar). 


\section{HET BELANG VAN EEN DYNAMISCHE WEERGAVE VAN ACTIES \\ VOOR PERSONEN MET AFASIE}

\section{Materiaal en procedure}

Het materiaal voor experiment 1 bestond uit een actie benoemtaak bestaande uit twee taken, namelijk een benoemtaak voor het produceren van werkwoorden op woordniveau $(\mathrm{N}=20)$ en een benoemtaak voor het produceren van werkwoorden op zinsniveau $(\mathrm{N}=20)$. De benoemtaken werden zowel aangeboden in de statische conditie met foto's $(\mathrm{N}=40)$ als in de dynamische conditie met video's $(\mathrm{N}=40)$ waarbij de doelitems gelijk waren per conditie. Het materiaal werd gepresenteerd op een computerscherm met behulp van het computerprogramma PowerPoint.

Voorafgaand aan het daadwerkelijke experiment werd er een pilot uitgevoerd bij een groep gezonde controleproefpersonen $(\mathrm{N}=12)$ om te onderzoeken of de geselecteerde foto's en video's de doelacties daadwerkelijk uitbeeldden. Slecht herkenbare items werden verwijderd of vervangen.

De items werden gecontroleerd voor frequentie (via CELEX; Burnage, 1990), transitiviteit, instrumentaliteit en naamsverwantschap. Een overzicht van de gebruikte acties wordt weergegeven in appendix 1.

De dynamische conditie bestond uit de aanbieding van geluidloze video's van 4 seconden waarin een actie werd uitgevoerd. Ten behoeve van de statische conditie werden er foto's gemaakt. De foto's bestonden uit het meest herkenbare moment van de actie zoals weergegeven in de dynamische conditie. Dit moment werd bepaald door de onderzoekers. Deze foto's werden tevens gedurende 4 seconden aangeboden tijdens de experimenten. In figuur 1 wordt een voorbeeld gegeven van één van de items.

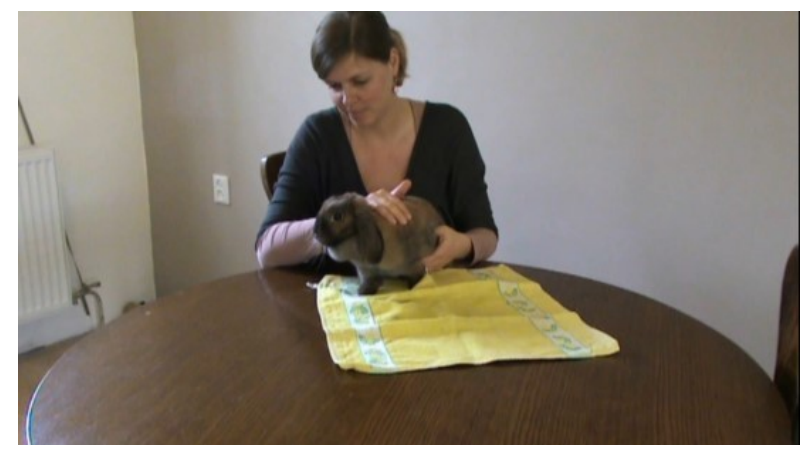

Figuur 1: Een voorbeeld van de statische conditie voor de actie 'aaien'. De statische conditie bestond uit schermafbeeldingen van het hoogtepunt van de video.

De tests in de statische en dynamische conditie werden verdeeld over twee sessies afgenomen, met een interval van een week. Er waren twee versies van iedere taak met beide een verschillende volgorde. De helft van de proefpersonen kreeg tijdens de eerste sessie 
GEERINK, PROSS, BROUWER DE KONING, BLANKESTIJN-WILMSEN, DAMEN, VOORBRAAK-TIMMERMAN, HURKMANS, JONKERS

statische stimuli aangeboden en tijdens de tweede sessie dynamische stimuli, waarbij werd gestart met de benoemtaak op woordniveau. De andere helft van de groep startte in de eerste sessie met de dynamische conditie.

Het experiment startte met een auditief aangeboden instructie, waarna twee oefenvoorbeelden volgden. Hierbij mocht de testleider hulp bieden. Vervolgens startte het experiment, hierbij werd geen hulp meer geboden. Het herhalen van een foto of video was maximaal één keer per item toegestaan indien de sessie werd onderbroken door derden, bij een moment van verminderde aandacht of wanneer de proefpersoon daarom vroeg. Bij het benoemen van acties luidde de instructie als volgt: 'U ziet steeds een foto/filmfragment. Kunt $\mathrm{u}$ in één woord zeggen hoe het heet wat diegene doet'. De instructie voor de subtest zinsformulering (statisch/dynamisch) luidde: ' $U$ ziet steeds een foto/filmfragment. Kunt $\mathrm{u}$ in één zin zeggen om wie het gaat en wat diegene doet'. Na iedere foto en video verscheen een zwart scherm. Dit scherm bleef zichtbaar totdat een antwoord was gegeven. De testleider bepaalde wanneer werd doorgegaan naar het volgende item.

De antwoorden van de proefpersoon werden opgenomen met een voice recorder en na afloop van de testafname door de onderzoeker uitgeschreven en gescoord op het daarvoor bestemde scoreformulier. Er werd een juist/onjuist systeem gehanteerd waarbij een juist antwoord 1 punt opleverde en een onjuist antwoord geen punten. Er was geen sprake van een tijdslimiet. De goedscore werd toegekend indien het doelwerkwoord werd genoemd ongeacht de vorm van het werkwoord, dus bijvoorbeeld het infinitief of een onjuiste vervoeging. Per item konden er ook verwante woorden anders dan het doelwoord juist worden gerekend. Er werd een lijst van synoniemen/bovenbegrippen opgesteld met antwoorden die ook als juist gescoord zijn, zie appendix 5 .

\section{Data-analyse}

Met een gepaarde t-test $(p<0.05)$ werd onderzocht of de PMA en de controleproefpersonen significant beter scoorden op de dynamische conditie dan op de statische conditie op woord- en zinsniveau.

\section{Resultaten}

De groep controleproefpersonen behaalde bij dit experiment zoals verwacht zeer hoge scores, zowel binnen de statische conditie op woordniveau $(M=18,25, S D=1,57)$ en op zinsniveau $(\mathrm{M}=19,38, \mathrm{SD}=0.81)$ als binnen de dynamische conditie op woordniveau $(\mathrm{M}=$ $19,01, \mathrm{SD}=1,23)$ en op zinsniveau $(\mathrm{M}=19,06, \mathrm{SD}=1,44)$. De controlegroep liet geen significante verschillen zien tussen de statische en dynamische conditie voor het benoemen van acties zowel in isolatie $(t(15)=-1.399, p=0.185)$ als op zinsniveau $(t(15)=0.924, p=$ 0.370). Daarom zal de bespreking van de resultaten zich steeds richten op de prestaties van 


\section{HET BELANG VAN EEN DYNAMISCHE WEERGAVE VAN ACTIES VOOR PERSONEN MET AFASIE}

de PMA. De ruwe scores van de patiëntengroep worden weergegeven in appendix 2.

De gepaarde t-test toonde aan dat de PMA in experiment 1 significant beter presteerden op het benoemen van acties op woordniveau (infinitief) in de dynamische conditie (M $=14.94, \mathrm{SD}=3.61)$ dan in de statische conditie $(\mathrm{M}=13.89, \mathrm{SD}=3.98), t(17)=-2.538, p=$ 0.021 . Ook voor de zinsconditie gold dat PMA significant beter presteerden in de dynamische conditie $(\mathrm{M}=14.11, \mathrm{SD}=3.4)$ in vergelijking met de statische conditie $(\mathrm{M}=13.5, \mathrm{SD}=$ 4.6), $t(17)=-2.502, p=0.023$. De resultaten worden grafisch weergegeven in figuur 2 .

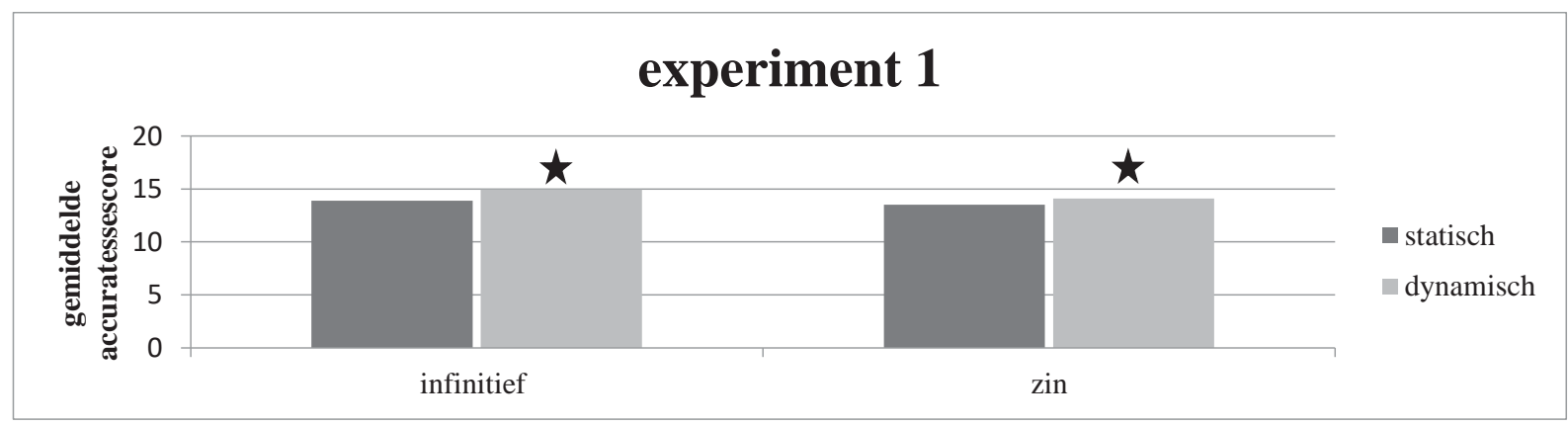

Figuur 2: Gemiddelde accuratessescore voor de statische en dynamische conditie voor het benoemen op woord- en zinsniveau.

\section{Discussie}

Uit de resultaten van experiment 1 is gebleken dat PMA, zowel op woord- als zinsniveau, significant beter scoorden in de dynamische conditie dan in de statische conditie. PMA blijken baat te hebben bij het zien van korte filmfragmenten bij het produceren van werkwoorden zowel op woordniveau als op zinsniveau. Deze uitkomsten sluiten aan bij de resultaten uit eerdere studies zoals het onderzoek van Druks en Shallice (2000) en D'Honincthun en Pillon (2008). Dynamisch materiaal, zoals een video, kan de bewegingskenmerken weergeven waardoor het gehele proces van de actie waargenomen kan worden. Dit kan betekenen dat een dynamisch aangeboden actie meer volledige informatie geeft over de semantische context (Druks \& Shallice, 2000) en dat de beschreven werkwoordstoornissen van PMA mogelijk deels te wijten zijn aan problemen in de conceptuele verwerking om de acties in statische weergaven te identificeren (d'Honicthun \& Pillon, 2008). Met andere woorden, door het afbeelden van acties op een statische manier wordt er veel belangrijke informatie weggelaten, zoals de beweging, waardoor er meer gevraagd wordt van een patiënt om deze acties te herkennen dan in een dynamische weergave. In experiment 2 is verder onderzocht in hoeverre semantische categorieën van invloed zijn op het benoemen van acties in een statische en dynamische conditie. Omdat in experiment 1 naar voren kwam dat het effect van dynamisch materiaal vergelijkbaar is op woord- en zinsniveau, heeft experiment 2 zich beperkt tot het oproepen van acties op woordniveau. 


\section{Experiment 2: De invloed van statisch en dynamisch aangebo- den acties op de productie van werkwoorden op woordniveau en de invloed van semantische categorieën}

\section{Proefpersonen}

Aan experiment 2 namen 13 PMA deel, drie vrouwen en tien mannen, met een gemiddelde leeftijd van 63 jaar (range: 40-77 jaar). Alle proefpersonen hadden afasie als gevolg van een ischemisch CVA links. De gemiddelde TPO van de PMA was 34 maanden (range: 8-264 weken). De afasie werd vastgesteld met behulp van de AAT (Graetz, et al., 1992). De proefpersonen die deelnamen aan dit experiment, namen niet deel aan experiment 1. Een overzicht van de PMA wordt weergegeven in tabel 2.

Naast PMA werden er 15 controleproefpersonen getest welke gematcht waren op basis van leeftijd aan de PMA. De groep met controleproefpersonen bestond uit acht mannen en zeven vrouwen, met een gemiddelde leeftijd van 55 jaar (range: 51-60 jaar). Ook de controleproefpersonen hebben niet deelgenomen aan experiment 1.

Tabel 2: Overzicht van de individuele gegevens van de afasiegroep voor experiment 2.

\begin{tabular}{llllllll}
\hline PP & Geslacht Leeftijd & Etiologie & Handigheid & $\begin{array}{l}\text { Opleidings- } \\
\text { niveau }\end{array}$ & TPO & $\begin{array}{l}\text { Score } \\
\text { benoemen }\end{array}$ \\
\hline A19 & Man & 64 & iCVA Links & Rechts & MBO & 37 & 109 \\
A20 & Man & 72 & iCVA Links & Links & ULO & 41 & 95 \\
A21 & Man & 64 & iCVA Links & Rechts & LTS & 64 & 64 \\
A22 & Man & 68 & iCVA Links & Rechts & MBO & 90 & 79 \\
A23 & Vrouw & 55 & iCVA Links & Rechts & MAVO & 45 & 97 \\
A24 & Man & 72 & iCVA Links & Rechts & LTS & 243 & 78 \\
A25 & Man & 61 & iCVA Links & Rechts & MBO & 8 & 95 \\
A26 & Man & 77 & iCVA Links & Rechts & MBO & 228 & 101 \\
A27 & Man & 69 & iCVA Links & Rechts & UTS & 257 & 83 \\
A28 & Man & 46 & iCVA Links & Links & MTS & 264 & 102 \\
A29 & Vrouw & 40 & iCVA Links & Links & HBO & 175 & 82 \\
A30 & Man & 71 & iCVA Links & Links & BO & 102 & 81 \\
A31 & Vrouw & 67 & iCVA Links & Rechts & HAVO & 211 & 108 \\
\hline
\end{tabular}

pp. = proefpersoon. Leeftijd in jaren. TPO $=$ time post onset in weken. . iCVA = ischemisch cerebro vasculair accident. Opleidingsniveau: $\mathrm{MBO}=$ middelbaar beroepsonderwijs, $\mathrm{ULO}=$ uitgebreid lager onderwijs, LTS = lagere technische school, MAVO = middelbaar algemeen voortgezet onderwijs, UTS = uitgebreide technische school, MTS = middelbare technische school, HBO = hoger beroepsonderwijs, $\mathrm{BO}=$ basisonderwijs, $\mathrm{HAVO}=$ hoger algemeen voortgezet onderwijs. Score AAT benoemen: $<107$ duidt op een 


\section{Materiaal en Procedure}

De test voor experiment 2 bestond uit een actie benoemtaak in de statische conditie $(\mathrm{N}=57)$ en de dynamische conditie ( $\mathrm{N}=57)$. In beide versies waren de items gelijk. De items waren op basis van hun semantische betekenis opgedeeld in ARM-gerelateerde acties $(\mathrm{N}=20)$, BEEN-gerelateerde acties $(\mathrm{N}=17)$ en GEZICHT-gerelateerde acties $(\mathrm{N}=20)$. De test werd in twee sessies afgenomen, waarbij de ene keer de statische conditie en de andere keer de dynamische conditie werd getest. Er waren twee versies van iedere taak met beide een verschillende volgorde. De test werd voorafgegaan door 3 oefenitems. Na 30 items was er een korte pauze.

Er werd, gelijk aan experiment 1, een pilot uitgevoerd om te onderzoeken of de geselecteerde foto's en video's de doelacties daadwerkelijk uitbeeldden. Slecht herkenbare items werden verwijderd of vervangen. Daarnaast werd er voor dit experiment een extra pre-test afgenomen bij een groep gezonde controleproefpersonen $(\mathrm{N}=10)$ om de acties te verdelen in de drie semantische categorieën BEEN, ARM en GEZICHT. Vervolgens werden de items gecontroleerd voor frequentie (Burnage, 1990). Een overzicht van de gebruikte acties wordt weergegeven in appendix 1.

Voordat de test begon, kregen de proefpersonen een auditief aangeboden instructie. Daarnaast werd de instructie ook visueel aangeboden. Op deze manier werden twee taalmodaliteiten aangesproken, voor een zo optimaal mogelijk begrip van de instructie. De instructie luidde als volgt: 'U ziet zo een foto/video. U mag in één woord proberen te zeggen wat de persoon op de foto/video doet'. Na de instructie werd er gestart met één oefenvoorbeeld uit iedere categorie. Om te controleren voor een eventueel vermoeidheidseffect werden er twee lijsten gehanteerd zodat de volgorde van aanbieding van de items verschilde. De procedure was verder gelijk aan experiment 1 . Evenals in experiment 1 konden er ook verwante woorden anders dan het doelwoord juist worden gerekend. Hiervoor werd een lijst van synoniemen/bovenbegrippen opgesteld met antwoorden die ook als juist gescoord zijn, zie appendix 6.

\section{Data-analyse}

De wijze van scoren was gelijk aan de scoring van experiment 1 . De totale scores van alle proefpersonen werden in percentages per proefpersoon berekend, omdat het aantal items per categorie niet gelijk was.

Er werd een gepaarde t-test uitgevoerd om de prestaties tussen de statische en de dynamische conditie binnen de groep met PMA met elkaar te vergelijken. Binnen de groep PMA is vervolgens onderzocht of er sprake was van significante verschillen tussen de drie categorieën tussen de statische en dynamische conditie met behulp van een gepaarde t-test. 
GEERINK, PROSS, BROUWER DE KONING, BLANKESTIJN-WILMSEN, DAMEN, VOORBRAAK-TIMMERMAN, HURKMANS, JONKERS

\section{Resultaten}

\section{Statisch versus dynamisch}

Ook binnen dit experiment lagen de gemiddelde scores van de controleproefpersonen boven de $90 \%$, zowel binnen de statische conditie $(\mathrm{M}=89.00, \mathrm{SD}=6.04)$ als binnen de dynamische conditie $(\mathrm{M}=92.37, \mathrm{SD}=5.33)$. Er was bij deze groep geen sprake van een significant verschil tussen de statische en dynamische conditie $(t(14)=1.94, p=0.07)$. Deze resultaten zijn daarom verder buiten beschouwing gelaten. De ruwe scores van de patiëntengroep worden weergegeven in appendix 3.

Uit een gepaarde t-test bleek dat de PMA in experiment 2 significant beter presteerden op het benoemen van acties in de dynamische conditie $(\mathrm{M}=72.38, \mathrm{SD}=10.25)$ dan in de statische conditie $(\mathrm{M}=66.77, \mathrm{SD}=12.00), t(12)=2.34, p=0.03$. De resultaten worden grafisch weergegeven in figuur 3.

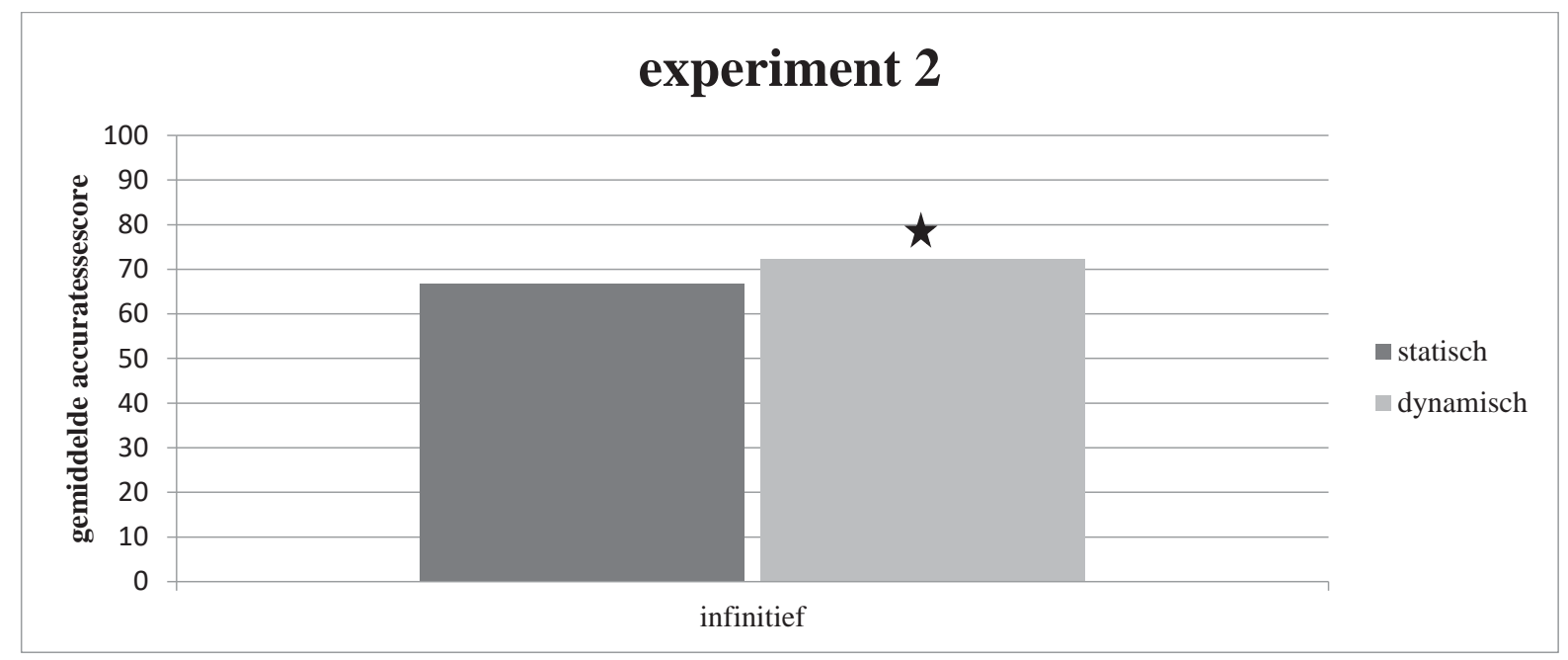

Figuur 3: Gemiddelde accuratessescore voor de statische en dynamische conditie voor het benoemen op woordniveau.

\section{Semantische categorieën}

Vervolgens werd er onderzocht of er een verschil bestond tussen de prestaties op de semantische categorieën ARM, BEEN en GEZICHT, afhankelijk van de conditie, namelijk statisch of dynamisch. Uit een gepaarde t-test bleek dat de PMA de ARM-gerelateerde acties significant beter benoemden binnen de dynamische conditie $(\mathrm{M}=76.54, \mathrm{SD}=13.29)$ dan binnen de statische conditie $(\mathrm{M}=65.38, \mathrm{SD}=18.10), t(12)=2.68, p<0.02$. De resultaten worden grafisch weergegeven in figuur 4 . Bij het benoemen van acties werden er geen significante verschillen gevonden tussen de statische GEZICHT-gerelateerde acties $(\mathrm{M}=71.54$, $\mathrm{SD}=13.90)$ en de dynamische GEZICHT-gerelateerde acties $(\mathrm{M}=73.08, \mathrm{SD}=13.16), t(12)$ $=0.52, p=0.61$ en tussen de statische BEEN-gerelateerde acties $(\mathrm{M}=63.92, \mathrm{SD}=11.27) \mathrm{en}$ de dynamische BEEN-gerelateerde acties $(\mathrm{M}=67.92, \mathrm{SD}=10.73), t(12)=1.16, p=0.27$. 
HET BELANG VAN EEN DYNAMISCHE WEERGAVE VAN ACTIES

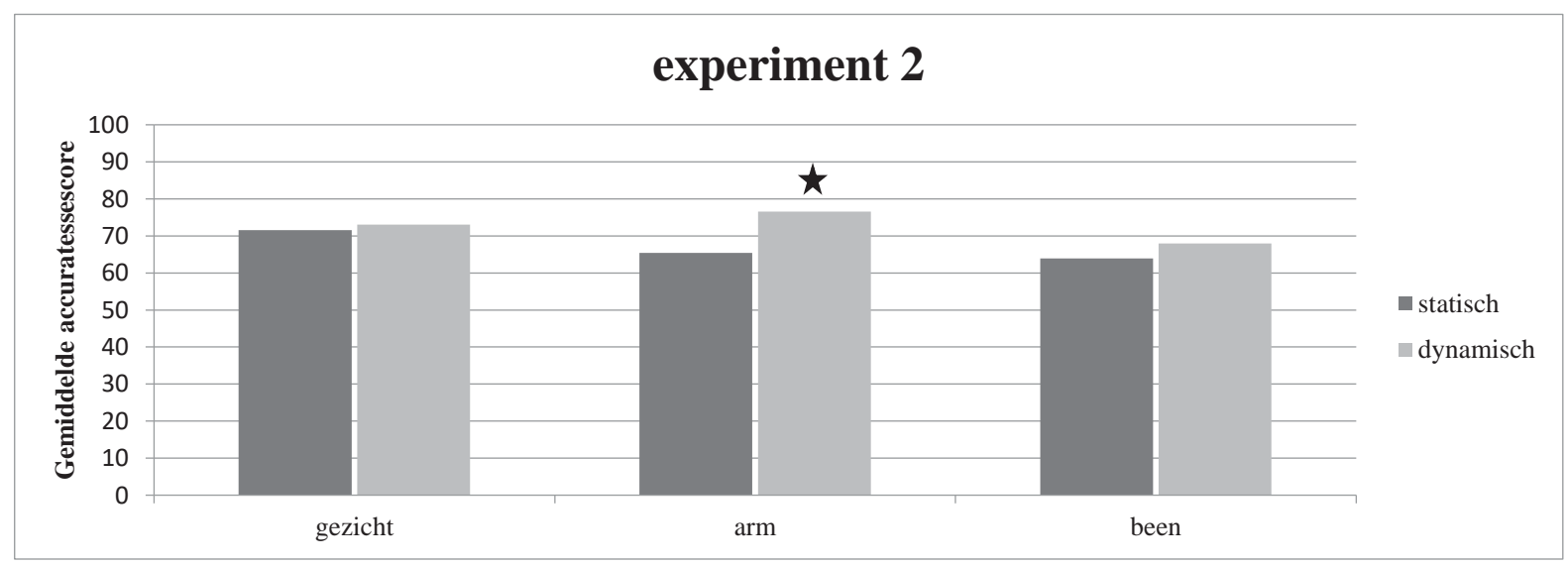

Figuur 4: Gemiddelde accuratessescore voor de semantische categorieën per conditie.

\section{Discussie}

Gelijk aan experiment 1 en een aantal andere studies (Druks \& Shallice, 2000; Fung et al., 2001; d'Honichthun \& Pillon, 2008) bleek ook uit experiment 2 dat PMA significant beter presteerden op het benoemen van acties in de dynamische conditie dan in de statische conditie.

Naast verschillen in prestaties tussen de condities werd er in experiment 2 ook verschil gemaakt tussen de drie semantische categorieën ARM, BEEN en GEZICHT. Uit de resultaten bleek dat bij de relatie tussen de verschillende semantische categorieën en de aard van de weergave PMA beter presteerden op de dynamische ARM-gerelateerde acties dan op de statische ARM-gerelateerde acties. Deze verschillen werden niet gevonden voor de BEENgerelateerde acties en de GEZICHT-gerelateerde acties. In de algemene discussie zal nader in gegaan worden op de mogelijke verklaringen voor de gevonden resultaten wat betreft de BEEN-gerelateerde en GEZICHT-gerelateerde acties.

Zowel in experiment 1 als in experiment 2 is aangetoond dat PMA beter presteren op het benoemen van acties wanneer deze acties dynamisch worden weergegeven. In experiment 3 is onderzocht of dit ook geldt voor het begrijpen van acties. Ook hierbij werd er onderscheid gemaakt in semantische categorieën, aangezien er in experiment 2 een verschil werd aangetoond op de productietaak tussen de prestaties op de semantische categorieën ARM, BEEN en GEZICHT, afhankelijk van de conditie. Enkele onderzoekers hebben zich al gericht op de invloed van verschillende semantische categorieën op het begrip, maar hierbij werd voor zover bekend niet de vergelijking tussen een statische en dynamische weergave gemaakt. Daarnaast wordt in experiment 3 onderzocht of het onderliggende afasietype hierop van invloed is. 


\section{EXPERIMENT 3: Het begrip van statisch en dynamisch aan- geboden acties op woord- en op zinsniveau en de invloed van semantische categorieën en afasietype}

\section{Proefpersonen}

Aan experiment 3 namen 17 PMA deel, acht mannen en negen vrouwen, met een gemiddelde leeftijd van 70 jaar (range: 40-91 jaar). De gemiddelde TPO was 9 maanden (range: 5-136 weken). Op basis van de Token Test (De Renzi \& Vignolo, 1962) werd de differentieel diagnose afasie gesteld. Het afasiesyndroom werd vastgesteld op basis van de ALLOCclassificatie bij het gebruik van de AAT (Graetz, et al., 1992). Bij het gebruik van de CAT-NL (Visch-Brink, Vandenborre, Jung de Smet \& Mariën, 2014) werd het afasiesyndroom door de klinisch linguïst vastgesteld op basis van de klinische observatie en de beschikbare onderzoeksgegevens. PMA werden geïncludeerd op basis van de aanwezigheid van een taalbegripsprobleem. Dit hield in dat de ruwe score op de taalbegripstaak van de AAT tussen de 20 (1e percentiel) en de 107 (91e percentiel) moest liggen (maximum score $=120$ ). Voor het domein 'taalbegrip' van de CAT-NL was het inclusiecriterium een ruwe score tussen de 18 en de 110 (maximum haalbare score $=124$, afkapwaarde $=107$ ). Deze ruwe scores wijzen op een minimale tot zware taalbegripsstoornis. Daarnaast werd er onderzocht of het onderliggende afasietype van invloed is op het verschil tussen de prestatie op de statische en dynamische conditie van de begripstaak. Dit werd gedaan op basis van de tweedeling tussen een vloeiend afasietype en een niet-vloeiend afasietype. In het kader van de somatotope weergave van de betekenis van actiewoorden in het brein wordt er verwacht dat het effect van de wijze van aanbieding verschillend is voor beide groepen. De lokalisatie van de stoornis verschilt namelijk tussen beide groepen en mogelijk bestaan er dus ook verschillen tussen de aan- of afwezigheid van een parese door de verstoring van het sensomotorische systeem, hetgeen mogelijk van invloed is op de prestaties op beide condities. De vloeiendheid werd beoordeeld met behulp van de Analyse van Spontane Taal Afasie (ASTA; Boxum, Van der Scheer \& Zwaga, 2010), hetgeen resulteerde in een groep personen met een vloeiend afasietype $(\mathrm{N}=7)$ en een groep personen met een niet-vloeiend afasietype $(\mathrm{N}=10)$. Deze PMA hebben niet deelgenomen aan experiment 1 of 2 . De gegevens van de PMA worden weergegeven in tabel 3.

Er namen 15 niet-taalgestoorde controleproefpersonen deel aan dit experiment, waarvan zes mannen en negen vrouwen. De gemiddelde leeftijd van de groep controleproefpersonen was 58 jaar (range: 44-87 jaar). De groep controleproefpersonen was gematcht met de groep PMA op basis van leeftijd. 
Tabel 3: Tabel 3 titel

\begin{tabular}{|c|c|c|c|c|c|c|c|c|c|}
\hline PP & Geslacht & Leeftijd & Etiologie & Handigheid & $\begin{array}{l}\text { Opleidings- } \\
\text { niveau }\end{array}$ & Afasie & VL/ & TPO & $\begin{array}{l}\text { Score be- } \\
\text { gripstaak }\end{array}$ \\
\hline A32 & Man & 76 & iCVA Links & Rechts & MTS & Globaal & NV & 40 & CAT-NL: 80 \\
\hline A33 & Man & 78 & iCVA Links & Rechts & MTS & Broca & NV & 136 & AAT: 48 \\
\hline A34 & Man & 69 & iCVA Links & Rechts & UTS & Gemengde & VL & 14 & CAT-NL: 109 \\
\hline A35 & Vrouw & 73 & iCVA Links & Links & ULO & Globaal & NV & 13 & CAT-NL: 84 \\
\hline A36 & Vrouw & 78 & iCVA Links & Rechts & LBO & Broca & $\mathrm{NV}$ & 60 & AAT: 73 \\
\hline A37 & Man & 91 & iCVA Links & Rechts & MTS & Wernicke & VL & 36 & AAT: 66 \\
\hline A38 & Man & 50 & iCVA Links & Rechts & LTS & Globaal & NV & 10 & CAT-NL: 78 \\
\hline A39 & Vrouw & 62 & iCVA Links & Rechts & LBO & Amnestisch & $\mathrm{VL}$ & 28 & AAT: 107 \\
\hline A40 & Man & 65 & iCVA Links & Rechts & MBO & Globaal & $\mathrm{NV}$ & 19 & CAT-NL: 60 \\
\hline A41 & Vrouw & 59 & iCVA Links & Rechts & MBO & Wernicke & VL & 10 & CAT-NL: 108 \\
\hline A42 & Man & 57 & iCVA Links & Rechts & MTS & Broca & NV & 44 & AAT: 81 \\
\hline A43 & Vrouw & 39 & iCVA Links & Rechts & MBO & Restafasie & VL & 29 & AAT: 105 \\
\hline A44 & Vrouw & 85 & iCVA Links & Rechts & LBO & Globaal & NV & 12 & CAT-NL: 38 \\
\hline A45 & Vrouw & 75 & iCVA Rechts & Links & LBO & Globaal & $\mathrm{NV}$ & 5 & CAT-NL: 46 \\
\hline A46 & Vrouw & 80 & iCVA Links & Rechts & LBO & Broca & 0 & 64 & AAT: 92 \\
\hline A47 & Vrouw & 66 & iCVA Links & Rechts & LBO & $\begin{array}{l}\text { Niet- } \\
\text { classificeer- } \\
\text { baar }\end{array}$ & VL & 37 & AAT: 77 \\
\hline A48 & Man & 70 & iCVA Links & Rechts & $\mathrm{HBO}$ & Amnestisch & VL & 19 & AAT: 87 \\
\hline
\end{tabular}

Leeftijd in jaren. iCVA = ischemisch cerebro vasculair accident. Opleidingsniveau: $\mathrm{LTS}=$ lagere technische school; ULO = uitgebreid lager onderwijs; UTS = uitgebreide technische school; MTS = middelbare technische school; MBO = middelbaar beroepsonderwijs; HBO $=$ hoger beroepsonderwijs. $\mathrm{NV}=$ niet-vloeiend. $\mathrm{VL}=$ vloeiend. $\mathrm{TPO}=$ time post onset in weken. Maximaal haalbare score AAT $=120$. AAT-score $<110$ duidt op een begripsstoornis. Maximaal haalbare score CAT-NL $=124$. CAT-score $<112$ duidt op een begripsstoornis.

\section{Materiaal en procedure}

De woordbegripstest en de zinsbegripstest bestonden beide uit 30 items, welke verdeeld werden in de drie semantische categorieën, namelijk BEEN-gerelateerde acties $(\mathrm{N}=10)$, ARMgerelateerde acties $(\mathrm{N}=10)$ en GEZICHT-gerelateerde acties $(\mathrm{N}=10)$. De werkwoorden zijn gematcht op frequentie op basis van de Celex-lijst (Burnage, 1990). Een overzicht van de gebruikte acties wordt weergegeven in appendix 1 .

Het experiment bestond uit een matchingtaak. Er werd gestart met een foto of video waarna er drie woorden of zinnen zowel auditief als visueel werden aangeboden. Een voorbeeld van een item wordt weergegeven in figuur 5. De auditief aangeboden antwoordmogelijkheden werden vooraf ingesproken door een vrouwelijke spreker. De antwoordmogelijkheden bestonden uit het doelwoord (bv. duwen), een semantisch-verwante afleider (bv. trekken) en een niet-verwante afleider (bv. snuiten). Op verzoek van de proefpersonen mochten de antwoordmogelijkheden auditief herhaald worden aangezien deze ook visueel zichtbaar bleven. De proefpersonen kregen een mondelinge en schriftelijke instructie aangeboden, verspreid over drie dia's. De instructie werd afhankelijk van de conditie aangebo- 
den, namelijk: 'U ziet een foto/video' (dia 1). 'Daarna hoort en leest u drie woorden/zinnen. De woorden/zinnen beschrijven wat de persoon doet' (dia 2). 'Wijs aan welk woord/welke zin het beste bij de foto/video past' (dia 3). De antwoorden werden door de testleider gescoord volgens een juist/onjuist systeem waarbij een juist antwoord 1 punt opleverde en een onjuist antwoord geen punten. Indien de proefpersoon de semantische afleider of nietverwante afleider aanwees werd het antwoord met 0 gescoord. De procedure was verder gelijk aan experiment 1 en 2 .

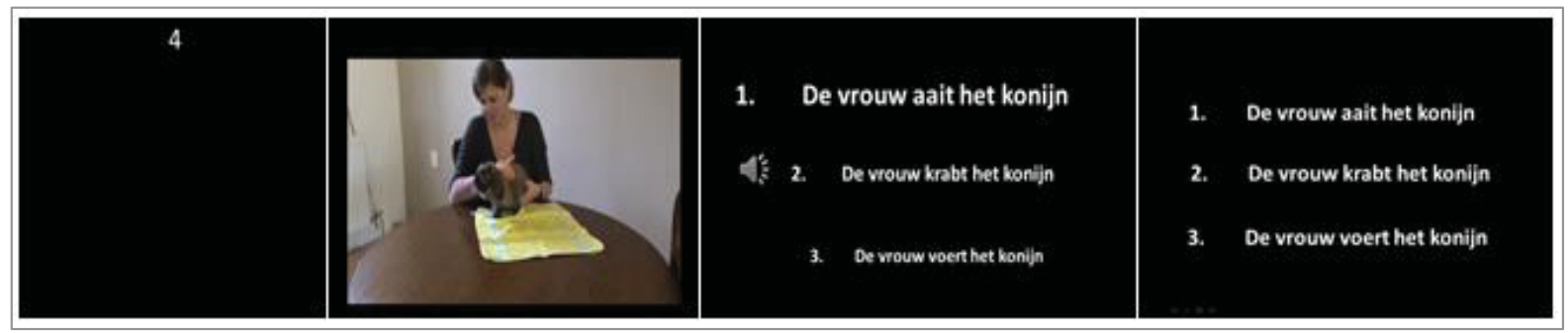

Figuur 5: Voorbeeld van de teststimulus voor het doelwerkwoord 'aaien'. Eerst verscheen er een zwart scherm met het itemnummer, vervolgens verscheen de foto of video welke gevolgd werd door een zwart scherm met drie antwoordmogelijkheden. De antwoorden werden één voor één vergroot, gelijktijdig met de auditieve aanbieding van de zin.

\section{Data-analyse}

Met behulp van de Wilcoxon signed-rank test werd onderzocht of er sprake was van significante verschillen tussen de prestaties binnen beide condities binnen de groep PMA. Daarnaast werd de Wilcoxon signed-rank test uitgevoerd om te onderzoeken of er per semantische categorie een significant verschil bestond tussen de prestaties binnen de statische en dynamische conditie.

Daarnaast werd onderzocht of het onderliggende afasietype van invloed is op de prestaties. De groep PMA is verdeeld in twee groepen, namelijk een groep personen met een vloeiende afasie $(\mathrm{N}=7)$ en een groep personen met een niet-vloeiende afasie $(\mathrm{N}=10)$. De Wilcoxon signed-rank test is uitgevoerd om te onderzoeken of er significante verschillen bestaan tussen de prestaties op de statische en dynamische conditie binnen beide groepen. De scores op de woord- en zinsbegripstaak werden samengenomen tijdens deze analyse.

\section{Resultaten}

De controlegroep scoorde op plafondniveau zowel binnen de statische conditie $(\mathrm{M}=29.8$, $\mathrm{SD}=0.6, \mathrm{Mdn} .=30.0)$ als binnen de dynamische conditie $(\mathrm{M}=30.0, \mathrm{SD}=0.1, \mathrm{Mdn} .=30.0)$. Daarom wordt de bespreking van de resultaten gericht op de prestaties van de afasiegroep. De ruwe scores van de patiëntengroep worden weergegeven in appendix 4 . 


\section{HET BELANG VAN EEN DYNAMISCHE WEERGAVE VAN ACTIES \\ VOOR PERSONEN MET AFASIE}

\section{Statisch versus dynamisch}

De Wilcoxon signed-rank test toonde aan dat PMA in experiment 3 significant beter presteerden op de dynamische woordbegripstaak (Mediaan $(\mathrm{Mdn})=28.0$.$) dan op de statische$ woordbegripstaak ((Mdn. $=26.0), z=-2.97, p=.003)$. Ook op de zinsbegripstaak presteerden PMA significant beter op de dynamische conditie $(\mathrm{Mdn} .=27.0)$ dan op de statische conditie ((Mdn. $=26.0), z=-2.79, p=.005)$. De resultaten worden grafisch weergegeven in figuur 6 .

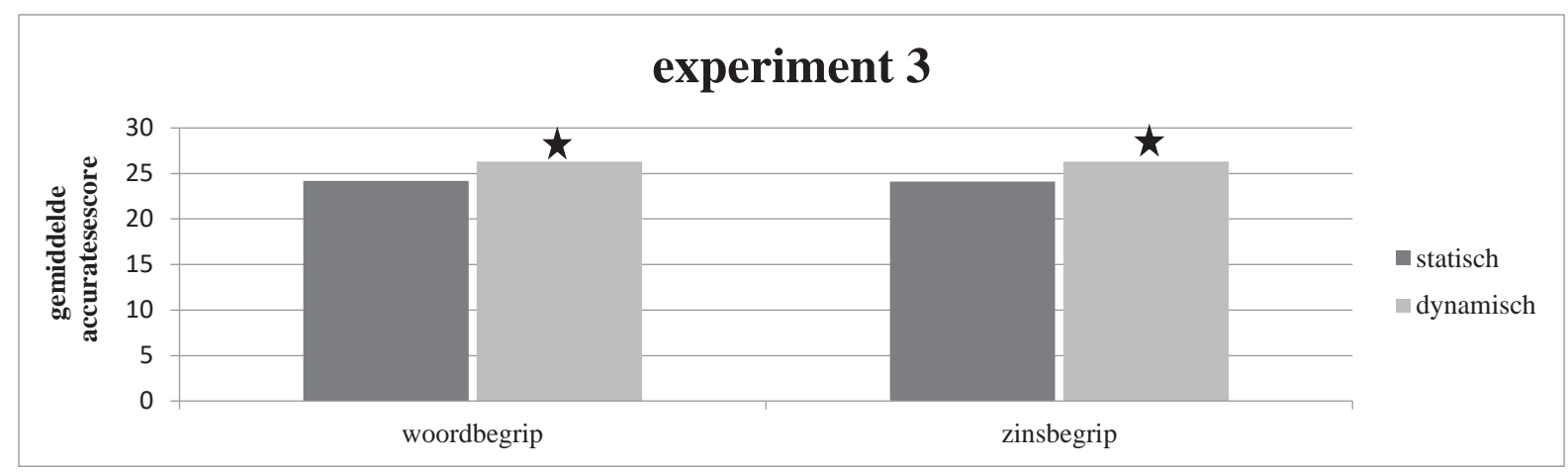

Figuur 6: Gemiddelde accuratesse voor de statische en dynamische conditie voor het begrip op woord- en zinsniveau.

\section{Semantische categorieën}

Binnen het derde experiment werd onderzocht of er een verschil bestond tussen de prestaties op de ARM-gerelateerde acties, BEEN-gerelateerde acties en GEZICHT-gerelateerde acties, afhankelijk van de conditie, namelijk statisch of dynamisch. De Wilcoxon signed-rank toonde aan dat PMA significant beter presteerden op de dynamische ARM-conditie (Mdn. $=19.0)$ dan op de statische ARM-conditie (Mdn. $=18.0),(z=-2.58, p=.010)$. Ook waren de prestaties op de dynamische BEEN-conditie (Mdn. = 18.0) significant beter dan op de statische BEEN-conditie (Mdn. $=17.0),(z=-2.615, p=.009)$. Er werd echter geen significant verschil aangetoond voor de prestaties tussen de statische GEZICHT-conditie (Mdn. = 18.0) en de dynamische GEZICHT-conditie (Mdn. $=19.0), z=-1.793, p=.073$. De resultaten worden grafisch weergegeven in figuur 7 .

\section{Afasietype}

Tot slot werd er binnen experiment 3 onderzocht of het onderliggende afasietype van invloed is op de gevonden resultaten. De vloeiend sprekende PMA presteerden significant beter binnen de dynamische conditie (Mdn. =59.0) dan binnen de statische conditie (Mdn. = 
55.0) van de begripstaak, $z=-2.032, p=.042$. Ook de niet-vloeiend sprekende PMA presteerden significant beter binnen de dynamische conditie (Mdn. $=50.5)$ dan binnen de statische conditie $(\mathrm{Mdn} .=47.0)$ van de begripstaak, $z=-2.558, p=.011$.

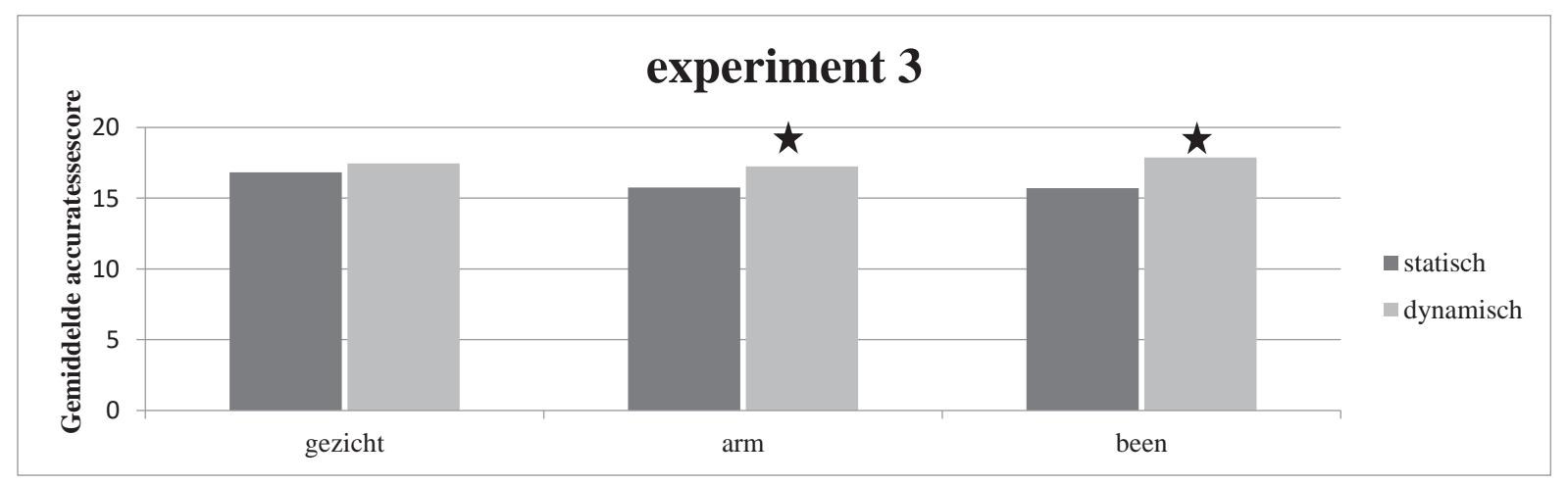

Figuur 7: Gemiddelde accuratessescore voor de semantische categorieën per conditie.

\section{Discussie}

\section{Statisch versus dynamisch}

In experiment 3 werd onderzocht of PMA beter presteerden op het begrijpen van acties in de dynamische conditie dan in de statische conditie, net zoals in experiment 1 en 2 aangetoond werd voor het benoemen van acties. Het voordeel van de dynamische weergave van acties blijkt ook voor begripstaken aanwezig te zijn op zowel woord- als zinsniveau. Voor zover bekend werd dit nog niet eerder aangetoond voor het begrip bij PMA. Berndt et al. (1997) hebben hun onderzoek ook verricht bij PMA, maar zij vonden geen significant verschil tussen het begrip van dynamisch aangeboden acties en statisch aangeboden acties. De tegenstrijdige resultaten kunnen verklaard worden op basis van de verschillen in de gehanteerde methode. Berndt et al. boden in hun matchingstaak twee video's tegelijkertijd aan op een scherm, gedurende 10 seconden. Vervolgens moesten de proefpersonen aangeven welke video bij het auditief aangeboden woord paste. Hoelang de afbeeldingen werden aangeboden wordt niet beschreven. Mogelijk konden de proefpersonen de acties in de statische conditie langer bekijken waardoor deze beter verwerkt konden worden ten opzichte van de acties in de dynamische weergave. Dit zou geleid kunnen hebben tot betere prestaties op de statische conditie. Bovendien is de aanbieding van 10 seconden een relatief lange tijd, waardoor een eventueel antwoord mogelijk langer vastgehouden moest worden. Het huidige experiment heeft hiervoor gecontroleerd door de stimuli in beide condities gedurende 4 seconden aan te bieden zodat het antwoord gedurende een relatief korte tijd vastgehouden hoefde te worden. Het herhalen van een foto of video was maximaal één keer per item toegestaan indien de sessie werd onderbroken door derden, bij een moment van verminderde aandacht of wanneer de proefpersoon daarom vroeg.

Bovendien werden in de studie door Berndt et al. niet dezelfde acties in de statische en dynamische conditie aangeboden, waardoor de prestaties op beide condities minder goed 
vergeleken konden worden. Het huidige experiment bood daarentegen exact dezelfde acties aan in beide condities, waarbij de foto's bestonden uit het meest herkenbare moment van de actie zoals weergegeven in de dynamische conditie, terwijl Berndt et al. lijntekeningen hanteerden in de statische conditie. Ook in dit opzicht verschillen beide studies hetgeen een verklaring kan geven voor de tegenstrijdige resultaten. Dit suggereert dat indien er gebruik gemaakt wordt van dezelfde items in beide condities en een even lange aanbiedingstijd van foto's en video's, er wel degelijk een verschil bestaat tussen het begrijpen van statisch en dynamisch aangeboden acties, in het voordeel van de dynamische conditie.

\section{Onderliggende afasietype}

In experiment 3 werd gevonden dat zowel personen met een niet-vloeiende afasie als personen met een vloeiende afasie significant beter presteerden op de dynamische conditie dan op de statische conditie van de begripstaken. Dit suggereert dat beide afasietypen een voordeel hebben van een dynamische weergave van acties met betrekking tot het begrip, ongeacht het soort afasie dat ze hebben en derhalve ook ongeacht de lokalisatie van de laesie. Desalniettemin moet er bij de interpretatie van de resultaten in acht genomen worden dat het onderzoek verricht is bij een kleine groep personen met een vloeiende en niet-vloeiende afasie en dat er geen gegevens beschikbaar zijn over de specifieke lokalisatie van de laesie en de aan- of afwezigheid van een parese van de patiënten die meededen aan het onderzoek.

\section{Semantische categorieën}

In experiment 3 werd gevonden dat het dynamisch aanbieden van ARM- en BEEN-gerelateerde acties het begrip verbetert vergeleken met een statische aanbieding. Deze resultaten zijn gedeeltelijk in lijn met de resultaten van zowel de studie naar het begrip van acties door Arévalo et al. (2012) als de studie naar de productie van acties in experiment 2. Hierop zal worden teruggekomen in de algemene discussie.

\section{ALGEMENE DISCUSSIE}

\section{Statisch versus dynamisch}

De huidige studie toonde op basis van drie experimenten aan dat de PMA significant beter presteerden op een test met dynamische weergaves van acties dan op een test met statische weergaves zowel bij de werkwoordproductietaken als de werkwoordbegripstaak en zowel op woord- als zinsniveau. Dit betekent dat de wijze van aanbieding van acties van invloed is op de werkwoordproductie en het werkwoordbegrip, in het voordeel van de dynamische conditie. Bovendien werd voor het werkwoordbegrip aangetoond dat dit voor zowel vloeiend als niet-vloeiend sprekende PMA geldt. Deze resultaten kunnen verklaard worden op basis van de veronderstelling dat acties moeilijker weer te geven zijn met behulp van statisch materiaal aangezien acties veelal uit bewegingen bestaan en over het algemeen dus 
GEERINK, PROSS, BROUWER DE KONING, BLANKESTIJN-WILMSEN, DAMEN, VOORBRAAK-TIMMERMAN, HURKMANS, JONKERS

niet stilstaand zijn. Dit betekent dat er met behulp van statisch materiaal maar een gedeeltelijke of incomplete representatie van de actie weergegeven kan worden (Fung et al., 2001). Daarentegen kan dynamisch materiaal, zoals een video, de bewegingskenmerken wel weergeven waardoor het gehele proces van de actie waargenomen kan worden. Dit kan betekenen dat een dynamisch aangeboden actie meer informatie geeft over de semantische context (Druks \& Shallice, 2000) en dat de beschreven werkwoordstoornissen van PMA mogelijk deels te wijten zijn aan problemen in de conceptuele verwerking om de acties in statische weergaven te identificeren (d'Honicthun \& Pillon, 2008). De resultaten komen overeen met eerdere studies waaruit bleek dat een dynamische weergave van acties een positieve invloed heeft op het benoemen van acties ten opzichte van een statische weergave van acties door PMA (Druks \& Shallice, 2000) en bij personen met de ziekte van Alzheimer (Fung et al., 2001; d'Honicthun \& Pillon, 2008). De huidige studie heeft aangetoond dat dit tevens voor het begrip van werkwoorden op zowel woord- als zinsniveau geldt.

Het feit dat diverse onderzoekers beweren dat PMA meer problemen hebben met het benoemen van acties dan met het benoemen van objecten (Mätzig et al., 2009; Willams \& Canter, 1987) en dat zowel vloeiend als niet-vloeiend sprekende PMA werkwoorden slechter begrijpen dan zelfstandige naamwoorden (McCarthy \& Warrington, 1985; Miceli et al., 1988) zou hiermee ook bekritiseerd kunnen worden. Mogelijk werd dit verschil in de literatuur veroorzaakt door het feit dat zelfstandige naamwoorden in een statische conditie minder afwijken van hoe ze in het dagelijks leven gezien worden dan actiewerkwoorden in een statische conditie.

De gevonden resultaten lijken verklaard te kunnen worden op basis van de 'Embodied Cognition Theory'. Volgens deze theorie wordt de semantische kennis van acties gerepresenteerd in het sensomotorische systeem in de hersenen (Caramazza et al., 2014). De dynamisch aangeboden acties worden beter begrepen en benoemd dan de statisch aangeboden acties doordat in de dynamische conditie de motorische kenmerken van de actie weergegeven worden, in tegenstelling tot in de statische conditie. Door het waarnemen van het gehele proces van de actie met de bijbehorende motorische kenmerken worden, uitgaande van de 'Embodied Cognition Theory', de motorische gebieden die verantwoordelijk zijn voor het daadwerkelijk uitvoeren van de actie sterker geactiveerd waardoor de actie beter verwerkt of opgehaald kan worden door het sensomotorische systeem. Dit leidt tot respectievelijk een beter begrip of betere productie van de actie.

De resultaten van de huidige studie kunnen echter eveneens geïnterpreteerd worden in het kader van de tegenhanger van de 'Embodied Cognition Theory', namelijk de 'Disembodied View of Cognition Theory', aangezien het niet duidelijk is of de sensomotorische processen noodzakelijk zijn voor de semantische verwerking van acties (Caramazza et al., 2014; Chatterjee, 2010; Humphreys, et al., 2013; Mahon \& Caramazza, 2008). De resultaten van de huidige studie zouden op basis van de 'Disembodied View of Cognition Theory' verklaard kunnen worden vanuit de veronderstelling dat in een dynamische weergave het gehele proces van de actie weergeven kan worden, terwijl een statische weergave maar een gedeelte- 


\section{HET BELANG VAN EEN DYNAMISCHE WEERGAVE VAN ACTIES VOOR PERSONEN MET AFASIE}

lijke of incomplete representatie van de actie weergeeft aangezien maar één moment van het gehele proces van de actie weergegeven wordt (Fung et al., 2001). Deze incomplete weergave leidt tot meer problemen met de activatie van de abstracte en symbolische representatie van het concept, waardoor de informatie ook minder goed opgehaald kan worden uit de motorische systemen. Daarentegen geeft de dynamische conditie wel de motorische kenmerken van de actie weer waardoor het concept beter geactiveerd wordt waarna de relevante informatie tevens beter opgehaald kan worden uit de motorische systemen, hetgeen leidt tot een beter begrip en een betere benoeming van de actie.

Het feit dat in experiment 3 aangetoond werd dat zowel de personen met een vloeiende afasie als de personen met een niet-vloeiende afasie baat hebben bij een dynamische weergave van acties sluit niet aan bij beide theorieën. Hoewel de lokalisatie van de laesie bij de vloeiend en niet-vloeiend sprekende PMA verschillend is, hebben beide groepen namelijk baat bij een dynamische weergave. Bij niet-vloeiende sprekers is er sprake van een frontale laesie en is vaak ook de motorische strip aangedaan, leidend tot pareses. Hierdoor zouden eerder problemen kunnen ontstaan met de verwerking van motorische informatie dan bij vloeiende sprekers met een temporale laesie, maar dit verschil werd niet gevonden in de huidige studie. Wel moet dit punt van kritiek met enige voorzichtigheid worden gebracht, want er zijn onvoldoende gegevens beschikbaar over de specifieke lokalisatie van de laesie en de aan- of afwezigheid van een parese van de PMA die deelnamen aan het huidige onderzoek.

\section{Semantische categorieën}

De huidige studie richtte zich tevens op de vraag of semantische categorieën van invloed zijn op het produceren en begrijpen van statisch en dynamisch weergegeven acties, waarbij onderscheid gemaakt werd tussen BEEN-gerelateerde acties, ARM-gerelateerde acties en GEZICHT-gerelateerde acties. Uit experiment 2 bleek dat het dynamisch aanbieden van ARM-gerelateerde acties de productie verbeterde vergeleken met een statische aanbieding. Experiment 3 toonde aan dat het dynamisch aanbieden van zowel ARM- als BEEN-gerelateerde acties het begrip verbeterde vergeleken met een statische aanbieding.

Deze resultaten zijn gedeeltelijk in lijn met de resultaten van de studie door Arévalo et al. (2012). Zij toonden aan dat het begrip van VOET-gerelateerde acties significant slechter was dan van VOET-neutrale acties in een statische conditie, terwijl dit sterke effect niet voor ARM- en GEZICHT-gerelateerde acties aangetoond werd. De verklaring die Arévalo et al. (2012) gaven voor de moeilijkheden met het begrijpen van VOET-gerelateerde acties zou tevens kunnen gelden voor het benoemen en begrijpen van ARM-gerelateerde acties, namelijk dat deze moeilijker weer te geven zijn op een foto en moeilijker uit te beelden zijn. Het feit dat de dynamische weergave het begrijpen van ARM- en BEEN- gerelateerde actiewerkwoorden en het benoemen van ARM-gerelateerde acties verbeterde kan tevens verklaard worden op basis van de veronderstelling dat de motorische kenmerken van de actie beter weergegeven worden in de dynamische conditie dan in de statische conditie doordat het gehele proces van de actie getoond wordt, waardoor de productie en het begrip verbetert. Een 
mogelijke verklaring voor het feit dat een dynamische weergave ten opzichte van een statische weergave van GEZICHT-gerelateerde acties niet heeft geleid tot een significant verschil voor productie en begrip is dat de GEZICHT-gerelateerde acties minder expliciete motorische kenmerken hebben dan BEEN- en ARM-gerelateerde acties, zoals bijvoorbeeld 'gorgelen', 'opblazen', 'niezen'. Daardoor zou de dynamische conditie minder voordelen bieden ten opzichte van de statische conditie. Een andere mogelijke verklaring heeft betrekking op het feit dat er binnen de GEZICHT-gerelateerde acties geen onderscheid werd gemaakt tussen GEZICHT-gerelateerde acties die gericht zijn op de communicatie en GEZICHT-gerelateerde acties die gericht zijn op het eten, omdat er onvoldoende acties beschikbaar zijn om hiervoor te kunnen controleren. Dit zou in een vervolgstudie meegenomen kunnen worden. Mogelijk zou een dynamische weergave wel een voordeel bieden ten opzichte van een statische weergave van acties indien er onderscheid gemaakt zou worden tussen verschillende soorten GEZICHT-gerelateerde acties.

\section{Aanbevelingen}

Het verdient aanbeveling om te onderzoeken of het onderliggende afasietype tevens van invloed is op de prestaties op de statische en dynamische conditie op werkwoordproductieniveau, net zoals dat voor het begrijpen is onderzocht. Daarnaast is het wenselijk om bij vervolgonderzoek zowel personen met een parese als personen zonder parese te includeren om te onderzoeken in hoeverre de aan- of afwezigheid van een parese en de daarmee gepaarde verstoring van het sensomotorische systeem een relatie vertoont met het functioneren van het talige netwerk. Daarbij dient gekeken te worden naar de invloed op de prestaties op de statische en dynamische conditie. Tevens verdient het aanbeveling om bij vervolgonderzoek gebruik te maken van beeldvormende technieken zoals (f)MRI om nader te onderzoeken of er inderdaad geen relatie bestaat tussen de lokalisatie van de laesie en het begrijpen van acties uit diverse semantische categorieën bij de PMA.

\section{Klinische implicaties}

De uitkomsten van de huidige studie hebben een aantal klinische implicaties. Ten eerste verdient het aanbeveling om binnen de linguïstische diagnostiek en therapie en binnen wetenschappelijk onderzoek bij PMA gebruik te maken van dynamisch materiaal in de vorm van video's, in plaats van gebruik te maken van het traditionele statische materiaal, zoals foto's en afbeeldingen, indien men zich richt op het benoemen en begrijpen van actiewerkwoorden. Het doel van linguïstische diagnostiek en therapie is immers het in kaart brengen van en het verbeteren van de communicatieve redzaamheid van de PMA in een situatie waarin alle acties dynamisch worden weergeven, vergelijkbaar met het dagelijks leven. Een test met statische afbeeldingen doet onvoldoende recht aan deze communicatieve competentie. Hierbij moet wel de kanttekening worden gemaakt dat geen enkele testsituatie een volledig representatief beeld geeft over hoe competent een spreker kan zijn in alledaagse communicatieve situaties. Aangezien er vrijwel geen dynamisch materiaal op de markt is dient dit in de toekomst ontwikkeld te worden. Tot slot dienen wetenschappers, klinisch 


\section{HET BELANG VAN EEN DYNAMISCHE WEERGAVE VAN ACTIES VOOR PERSONEN MET AFASIE}

linguïsten en logopedisten zich er bewust van te zijn dat het gebruik van statisch materiaal de prestaties op benoem- en begripstaken van actiewerkwoorden negatief kan beïnvloeden en dat het daardoor niet de meest optimale weergave geeft van wat PMA kunnen of van welke kennis deze personen nog in bezit zijn.

\section{Referenties}

Arévalo, A.L., Baldo, J.V. \& Dronkers, N.F. (2012). What do brain lesions tell us about theories of embodied semantics and the human mirror neuron system? Cortex, 48, 242-254.

Barsalou, L.W. (2008). Grounded cognition. Annual Review of Psychology, 59, 617-645.

Bastiaanse, R. (2011). Afasie. Houten, Nederland: Bohn Stafleu van Loghum.

Bastiaanse, Y. R. M., \& van Zonneveld, R. M. (2004). Broca's aphasia, verbs and the mental lexicon. Brain and Language, 90(1-3), 198 - 202.

Berndt, R., Mitchum, C., Heandiges, A. \& Sandson, J. (1997). Verb retrieval in aphasia 1. Characterizing single word impairments. Brain and Language, 56, 68-106.

Boxum, E., Van der Scheer, F., Zwaga, M. (2010). Analyse voor Spontane Taal bij Afasie (ASTA). Vereniging voor Klinische Linguïstiek.

Burnage, G. (1990). A Guide for Users. Nijmegen, CELEX Centre for Lexical Information.

Caramazza, A., Anzellotti, S., Strnad, L. \& Lingnau, A. (2014). Embodied cognition and mirror neurons: A critical assessment. Annual Review of Neuroscience, 37, 1-15.

Chatterjee, A. (2010). Disembodying cognition. Language and Cognition, 2, 79-116.

De Renzi, E., Vignolo, L.A. (1962). The Token Test: A sensitive test to detect receptive disturbances in aphasics. Brain, 85; 665-678.

d'Honincthun, P. \& Pillon, A. (2008). Verb comprehension and naming in frontotemporal degeneration: the role of the static depiction of actions. Cortex, 22, 834-847.

Druks, J. \& Shallice, T. (2000). Selective preservation of naming from description and the "Restricted Preverbal Message". Brain and Language, 72, 100-128.

Fung, T., Chertkow, H., Murtha, S., Whatmough, C., Péloquin, L., Whitehead, V. \& Templeman, F. (2001). The spectrum of category effects in object and action knowledge in dementia of the Alzheimer's type. Neuropsychology, 15(3) 371-379.

Gallese, V., Lakoff, G. (2005). The Brain's concepts: the role of the sensory-motor system in conceptual knowledge. Cognitive Neuropsychology, 22, 455-479.

Graetz, P., De Bleser, R. \& Willmes, K. (1992). Akense Afasie Test (AAT). Lisse: Swets Test Publishers.

Grodzinsky, Y. (1995). A restrictive theory of agrammatic comprehension. Brain and Language, 51, 26-51.

Grossman, M., Koenig, P. DeVita, C., Glosser, G., Alsop, D., Detre, J., \& Gee, J. (2002). Neural Representation of Verb Meaning: An fMRI Study. Human Brain Mapping, 15, 124-134.

Hauk, O., Johnsrude, I. \& Pulvermüller, F. (2004). Somatotopic respresentations of action words in human motor and premotor cortex. Neuron, 41, 301-307.

Humphreys, G.F., Newling, K., Jennings, C. \& Gennari, S.P. (2013). Motion and actions in language: Semantic representations in occipito-temporal cortex. Brain and Lan- 
GEERINK, PROSS, BROUWER DE KONING, BLANKESTIJN-WILMSEN, DAMEN, VOORBRAAK-TIMMERMAN, HURKMANS, JONKERS

guage, 125, 94-105.

Jeannerod, M. (2001). Neural simulation of action: a unifying mechanism for motor cognition. NeuroImage, 14, 103-109.

Jonkers, R. (1998). Comprehension and production of verbs in aphasic speakers. Groningen, GRODIL (Groningen Dissertations in Linguistics) 25.

Jonkers, R. \& Bastiaanse, R. (2007). Action naming in anomic aphasic speakers: Effects of instrumentality and name relation. Brain and Language, 102, 262-272.

Kim, M. \& Thompson, C.K. (2000). Patterns of comprehension and production of nouns and verbs in agrammatism: Implications for lexical organization. Brain and Language, $74,1-25$.

Kim, M. \& Thompson, C.K. (2004). Verb deficit in Alzheimer's disease and agrammatism: Implications for lexical organization. Brain and Language, 88, 1-20.

Mahon, B.Z. \& Caramazza, A. (2008). A critical look at the embodied cognition hypothesis and a new proposal for grounding conceptual content. Journal of Physiology, 102, 5970.

Mätzig, S., Druks, J., Masterson, J. \& Vigliocco, G. (2009). Noun and verb differences in picture naming: Past studies and new evidence. Cortex, 45, 738-758.

McCarthy, R. \& Warrington, E.K. (1985). Category specificity in an agrammatic patient: The relative impairment of verb retrieval and comprehension. Neuropsychologia, 23, 709727.

Miceli, G., Silveri, M.C., Nocenti, U. \& Caramazza, A. (1988). Patterns of dissociation in comprehension and production of nouns and verbs. Aphasiology, 2, 351-358.

Plaut, D.C. \& Shallice, T. (1993). Deep dyslexia: a case study of connectionist neuropsychology. Cognitive Neuropsychology, 10, 377-500.

Pulvermüller, F. (2005). Brain mechanisms linking language and action. Nature Reviews Neuroscience, 6, 576-582.

Pulvermüller, F., Härle, M. \& Hummel., F. (2001). Walking of talking?: Behavioral and neurophysiological correlates of action verb processing. Brain and Language, 78, 143-168.

Pulvermüller, F., Hauk, O., Nikulin, V.V., \& Ilmoniemi, R.J. (2005). Functional links between motor and language systems. European Journal of Neuroscience, 21, 793- 797.

Rizzolatti, G. \& Sinigaglia, C. (2010). The functional role of the parieto-frontal mirror circuit: interpretations and misinterpretations. National Review of Neuroscience, 11, 264274.

Schwanenflugel, P.J. (1991). Why are abstract concepts hard to understand? In: Schwanenflugel, P.J., ed. The psychology of word meanings. Hillsdale, NJ: Lawrence Erlbaum Associates Inc.

Schwanenflugel, P.J. \& Shoben, E.J. (1983). Differential context effects in the comprehension of abstract and concrete verbal materials. Journal of Experimental Psychology, 9, 82-102.

Shiffrar, M., \& Freyd, J.J. (1990). Apparent motion of the human body. Psychological Science, $1,257-264$.

Tettamanti, M., Buccino, G., Saccuman, M.C., Gallese, V., Danna, M., Scifo, P., et al. (2005). Listening to action-related sentences activates fronto-parietal motor circuits. Journal 


\section{HET BELANG VAN EEN DYNAMISCHE WEERGAVE VAN ACTIES

of Cognitive Neuroscience, 17, 273-281.

Thompson, C.K. (2003). Unaccusative verb production in agrammatic aphasia: The argument structure complexity hypothesis. Journal of Neurolinguistics, 16, 151-167.

Tranel, D., Manzel, K., Asp, E. \& Kemmerer, D. (2008). Naming dynamic and static actions: Neuropsychological evidence. Journal of Physiology - Paris, 102, 80-94.

Verfaille, K., \& Daems, A. (2002). Representing and anticipating human actions in vision. Visual Cognition, 9, 217-232.

Visch-Brink, E., Vandenborre, D., Jung de Smet, H., \& Mariën, P. (2014). Comprehensive Aphasia Test-Nederland. Nederlandse bewerking (CAT-NL). Pearson.

Williams, S.E. \& Canter, G.J. (1987). Action-naming performance in four syndromes of aphasia. Brain and Language, 32, 124-136.

Zwaan, R.A., \& Taylor, L.J. (2006). Seeing, acting, understanding: motor resonance in language comprehension. Journal of Experimental Psychology: General, 135, 1-11. 